\title{
Determination of $M_{\max }$ from Background Seismicity and Moment Conservation
}

\author{
by V. L. Stevens and J.-P. Avouac
}

\begin{abstract}
We describe a simple method to determine the probability distribution function of the magnitude $M_{\max }$ and return period $T_{R}$ of the maximum plausible earthquake on crustal faults. The method requires the background seismicity rate (estimated from instrumental data) and the rate of interseismic moment buildup. The method assumes that the moment released by the seismic slip is in balance with the moment deficit accumulated in between earthquakes. It also assumes that the seismicity obeys the Gutenberg-Richter (GR) law up to $M_{\max }$. We took into account the aftershocks of large infrequent events that were not represented in the instrumental record, so that we could estimate the average seismicity rate over the entire fault history. We extrapolated the instrumental record, using the GR law to model the frequency of larger events and their aftershocks. This increased the frequencies of smaller events on average; when these smaller events were newly extrapolated, they predicted a higher frequency of larger events. We iterated this process until stability was reached, and then we assumed moment balance when we found the maximum magnitude; we have found this method to be appropriate in applications involving examples of fault with good historical catalogs. We then showed examples of applications to faults with no historical catalogs. We present results from nine cases. For the San Andreas fault system, we find $M_{\max }=8.1 \pm 0.3$, with $T_{R} 380_{120}^{950} \mathrm{yrs}$; for the North Anatolian fault, $M_{\max }=$ $8.0 \pm 0.3$, with $T_{R} 275_{135}^{650} \mathrm{yrs}$; for the Main Himalayan thrust, $M_{\max }=9.0 \pm 0.2$, with $T_{R} 1200_{550}^{2700} \mathrm{yrs}$; for the Japan trench, $M_{\max }=9.3 \pm 0.3$, with $T_{R} 520_{220}^{1200} \mathrm{yrs}$; for the Sumatra-Andaman trench, $M_{\max }=9.0 \pm 0.3$, with $T_{R} 200_{80}^{450} \mathrm{yrs}$; for the Boconó fault, $M_{\max }=7.3 \pm 0.3$, with $T_{R} 160_{70}^{360} \mathrm{yrs}$; for the Altyn Tagh fault, $M_{\max }=8.0 \pm 0.3$, with $T_{R} 900_{400}^{2000} \mathrm{yrs}$; for the Dead Sea Transform, $M_{\max }=$ $7.8 \pm 0.3$, with $T_{R} 1000_{450}^{2400} \mathrm{yrs}$; and for the Kunlun fault, $M_{\max }=8.0 \pm 0.3$, with $T_{R} 1000_{450}^{2000} \mathrm{yrs}$.
\end{abstract}

\section{Introduction}

The magnitude $M_{\max }$ and return period of the maximum earthquake on a particular fault or in a certain area are important parameters in seismic-hazard analysis. This information is most commonly derived from historical data; that is, from the estimated magnitudes of earthquakes based on written records of shaking and building damage. In these cases, an a priori model of the magnitude-frequency distribution is typically assumed. Generally, seismicity is assumed to follow the Gutenberg-Richter (GR) law (Gutenberg and Richter, 1944). One common difficulty is that in the absence of any physical constraints on the maximum possible earthquake, the distribution is unbounded, and the maximum plausible earthquake depends on the time period considered (Holschneider et al., 2011; Zöller and Holschneider, 2016). There is, however, a physical limit, due to the fact that strain due to seismicity must match the strain resulting from geo- logical motion across the fault on average over geological time (Brune, 1968). If the fault-slip rate is known, additional constraints on the seismicity model can thus be derived based on the seismic moment budget (e.g., Molnar, 1979; Ader et al., 2012; Kagan and Jackson, 2013; Rong et al., 2014; Avouac, 2015; Bird et al., 2015; Stevens and Avouac, 2016). There is now abundant evidence that seismic slip occurs in locations where faults were locked previously; this information can be gathered from geodetic observations (e.g., Avouac, 2015). As a result, geodetic data can be used to determine the rate of elastic strain buildup that will be released by any given earthquake, although this can also be estimated from the fault area and the long-term slip rate given that we know the average interseismic coupling (which represents the proportion of the fault that is locked in the interseismic period). We use the rate of elastic strain buildup in a moment 
budget balance with the rate of elastic strain release through earthquakes, so that we can avoid the problem of having an unbounded earthquake distribution (described in more detail below).

We describe here a simple method that does not require any historical data of large earthquakes and assumes simply that the seismicity obeys the GR law:

$$
\log \left(N\left(M>M_{\mathrm{w}}\right)\right)=a-b M_{\mathrm{w}}
$$

(Gutenberg and Richter, 1944), in which $N\left(M>M_{\mathrm{w}}\right)$ is the number of earthquakes above $M_{\mathrm{w}}, a$ is the $y$-axis intercept and can be thought of as the productivity, and $b$ is the slope of the line. The method only requires knowledge of the fault geometry, the long-term slip rate of the fault, and some earthquake catalog at the regional scale. More sophisticated methods can be used in areas with abundant information. The method here is most appropriate to regions where there is little information on past seismicity, fault-slip rates, and interseismic geodetic loading; however, an earthquake catalog and estimated faultslip rate are needed. Hereafter, we describe typical methods of finding $M_{\max }$, the use of instrumental data, and the probability that seismicity rate changes with time. We then describe our method and demonstrate that it performs relatively well when applied to case examples with relatively abundant data. We next apply it to less well-constrained examples.

\section{Usual Methods}

One common method to estimate $M_{\max }$ is simply to use the largest earthquake in the historical record and add 0.5 (Kijko and Graham, 1998; Sokolov et al., 2001). There is no statistical foundation to that approach. It can be seen as a reasonable assumption in cases where the historical catalog is long enough to represent the long-term average. In these cases, the 0.5 added to the magnitude would represent a safety factor, accounting for the uncertainty on magnitude and for the finite number of events in the earthquake catalog. This approach is questionable if the historical record is limited, in which case it may greatly underestimate $M_{\max }$. Another deterministic method relies on scaling relations between the length of the fault and the maximum earthquake, using, for example, the empirical relationships of Wells and Coppersmith (1994). This method can be applied in cases where there is no historical data. Issues arise typically when deciding whether to divide the fault into segments, and if so, how it is to be done. In addition, earthquakes can rupture separate segments; for example, both the 1992 Landers (Sieh et al., 1993) and the 2011 Tohoku-Oki earthquakes (Fry and Ma, 2016) exceeded the maximum magnitude that would have been expected from this approach. The possibility that earthquakes can link different fault segments thus needs to be taken into account (Field et al., 2014).

Alternatively, statistical methods can be used to estimate $M_{\max }$ (e.g., Kijko, 2004). In these approaches, the magnitude-frequency distribution of earthquakes can be assumed to follow a truncated GR distribution (Kijko, 2004; Holschneider et al., 2011). It is also possible to use a magnitude-frequency distribution with no a priori prescribed analytical shape (e.g., Kijko, 2004). Other methods use the theory of extreme values of random variables (Pisarenko et al., 2008, 2010). These various methods are based only on the observed seismicity data. They are ineffective in cases where the observed seismicity is not representative of the long-term progress and trends reflected in the data. This might happen if the maximum earthquake has a return period longer than the period covered by the data, or if seismicity rate or the magnitude-frequency distribution of earthquakes fluctuates at periods larger than the period covered by the data. In the absence of physical constraints on $M_{\max }$, and if the maximum possible event is not constrained by the observed seismicity, then the magnitude of the maximum event expected at a certain confidence level would grow without limit as the time range becomes larger (e.g., Holschneider et al., 2011; Zöller and Holschneider, 2016). In our method, we simulate potential complete earthquake catalogs on each fault in an attempt to overcome the problem of the limited time period of observed seismicity.

For simplicity, our analysis assumes a seismicity model represented by a truncated GR distribution. It would be possible to relax this assumption and use a different seismicity model, eventually using a nonparametric seismicity model.

\section{Model}

We assume a doubly truncated GR distribution, with $M_{\max }$ being the hard upper limit and the lower limit being the magnitude below which the seismicity record is not complete (because of the fact that not all smaller events are reported). We enforce moment conservation; that is, we enforce the principle of the moment deficit buildup due to interseismic loading of a fault being equal to the moment release on that fault by both seismic and transient aseismic slips. We model the average earthquake catalog for the entire fault history by adding on larger earthquakes and their modeled aftershocks according to the GR law, and then we find the upper magnitude of this catalog that balances the moment budget. This is visualized in Figure 1a. The thick straight line shows the relationship between the frequency and magnitude of the maximum earthquake that is needed for each magnitude to balance the moment buildup:

$$
N=\log _{10} \frac{\dot{M}_{\circ r}}{10^{\alpha-b M}-1}-\beta-\log _{10} b-\log _{10} 3-b M,
$$

in which $N$ is the frequency of earthquakes, $M_{\mathrm{w}}$ is the magnitude, $\dot{M}_{\circ r}$ is the moment deficit buildup rate in $\mathrm{N} \cdot \mathrm{m} / \mathrm{s}$, $\alpha=3 / 2, \beta=9$, and $b$ is from the GR relationship, often close to 1 . The slope of this line is roughly $-3 / 2$. See the Appendix for the derivation of this equation. The seismicity model will also form a line on this plot, as it is assumed to obey the GR law. Provided that the $b$-value is less than 

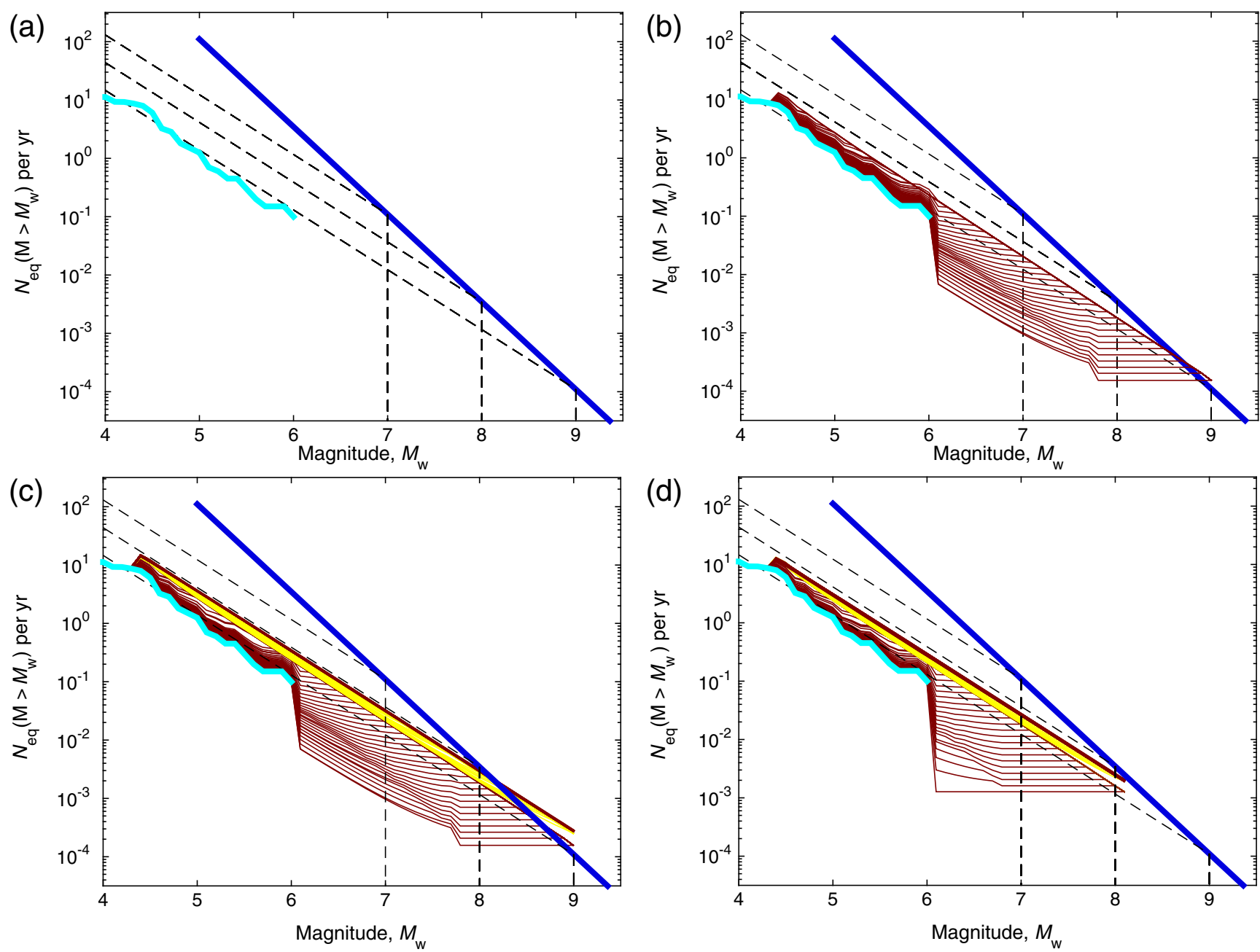

Figure 1. Demonstrating steps of the method. The thick straight line is moment buildup rate line, which shows the frequency of the maximum magnitude earthquake that would need to occur to take up the entire moment buildup. The lower line is the instrumental catalog, here from the San Andreas fault system (SAFS) and unclustered, over the 1996-2016 period. The dashed lines demonstrate the GutenbergRichter law with a $b$ of 1 , which is where the earthquake catalog should lie to intersect maximum magnitudes of 7, 8, and 9. (a) The original setup. (b) Thin lines show the first round of adding on missing earthquakes from magnitude 9 down to the cutoff magnitude, here 4.4. (c) Two more cycles of thin lines have now been added - these show two more rounds of adding on missing earthquakes. The number needed to be added on decreases with each round, which is why the lines get closer and closer together. (d) Same as (c) but now showing a trial maximum magnitude of 8.1, which is the maximum magnitude that is predicted. The color version of this figure is available only in the electronic edition.

$3 / 2$, the two lines intersect at the maximum earthquake of the seismicity model. This is the case for the various models represented by the dashed lines. The issue is then to determine which model would provide the best estimate of the known seismicity.

The method requires only an instrumental earthquake record and an estimate of the seismic moment deficit buildup rate. This rate $\dot{M}_{\circ r}$ can be calculated either from interseismic coupling models where available or, alternatively, one can assume a mean coupling, which would represent the proportion of the width of the fault from the surface to the bottom of the seismogenic depth that slips during episodic slip events. The calculation can be done as follows:

$$
\dot{M}_{\circ r}=\mu L W \bar{u}
$$

in which $\dot{M}_{\circ}$ is the moment rate buildup, $\mu$ is the rigidity (here assumed to be $33 \mathrm{GPa}$ for continental faults and $50 \mathrm{GPa}$ for subduction zones), $L$ is the length of the fault, $W$ is the coupled width of the fault, and $\bar{u}$ is the average slip rate along the fault. The coupled width of the fault is only a fraction of the width of the depth of the seismogenic zone, given that some aseismic creep occurs in the seismogenic depth range in the interseismic period. The brittle-ductile transition is around $8-15 \mathrm{~km}$ in the continents (e.g., Kohlstedt et al., 1995), and the effective seismic depth of continental lithosphere (determined from the depth distribution of seismic moment release) is around $8.6_{-4}^{+11} \mathrm{~km}$ in the absence of aseismic transients (Bird and Kagan, 2004). Here, we take a default coupled width of $12.5 \pm 2.5 \mathrm{~km}$ for continental strikeslip faults. For subduction zones, we use the down-dip width 
of the seismogenic zone of the plate interface; this is estimated from the distribution of interplate earthquakes. Within the seismogenic zone, we assume a coupling of $45 \%$, which is a rough average value that represents subduction zones all over the world (Avouac, 2015).

A major source of uncertainty in our method has to do with the proportion of moment buildup released by earthquakes and aseismic transients, respectively. Transient aseismic slip events can take the form of afterslip that follows the large earthquakes or spontaneous slow-slip events. Estimating this proportion requires a well-constrained moment budget over the full seismic cycle, and there are only a few areas where the budget can be worked out (e.g., Avouac, 2015, and references therein). Hereafter, based on these case examples, we assume that aseismic transients release an average of $0 \%-20 \%$ of the interseismic moment deficit.

We solve for $M_{\max }$ using an iterative procedure that is described below. In this procedure, the budget takes into account the moment released by large events. This includes the contributions from their aftershocks and afterslip, which would not be represented in the seismicity catalog if a large event has not occurred after the start of instrumentation. We use a numerical Monte Carlo procedure to generate earthquake catalogs. We typically generate 100,000 catalogs in each example, with the full procedure taking a few minutes of computational time on a standard laptop. Uncertainties in the input parameters, such as the $b$-value, can take any form and are propagated through the model to get uncertainties in $M_{\max }$ and recurrence times.

\section{$b$-Value}

Because we are interested in quantifying the moment released by earthquakes, the relevant magnitude scale involves the moment magnitude $M_{\mathrm{w}}$. The seismicity is observed generally to follow the GR law (equation 1, Gutenberg and Richter, 1944), with $b$-values observed generally to be around 1 . Instrumental global seismicity yields a $b$-value of 0.93-0.98 (Bird and Kagan, 2004; Kagan and Jackson, 2012), and the average $b$-value for continental strike-slip faults is $\sim 0.98$ (Bird and Kagan, 2004). Regional estimates are similar. For example, different studies of the seismicity of California report values of 0.9 (Bakun, 1999), 0.95 (Tormann et al., 2010), $1.02 \pm 0.11$ (Felzer, 2008), $1.03 \pm 0.12$ (Page and Felzer, 2015), and 1.05 (Marsan and Lengliné, 2008). A value of about 1 was also determined from both historical and instrumental catalogs (Felzer et al., 2004; Wang et al., 2009; Hutton et al., 2010; Field et al., 2014). These regional $b$-values are close to the $b$-values obtained from individual earthquake sequences; for example, the value was $1.09 \pm 0.9$ for the Landers aftershocks (Felzer et al., 2002). However, there are significant variations, depending on the areas studied, tectonic settings, catalogs used, the method used to determine the cutoff magnitude and $b$-values, and errors in the magnitudes of historical earthquakes (Zöller et al., 2010).
Japan is another well-documented area with a spread of values but a general convergence of $b$-values around 1 (e.g., Bird and Kagan, 2004; Grunewald and Stein, 2006; Parsons et al., 2012; Omi et al., 2013; Toda and Stein, 2013; Satake, 2015). For example, the analysis of 92 years of historical data (Satake, 2015) yielded a $b$-value of 0.88 , and the aftershocks of Tohoku-Oki yielded a $b$-value range of 0.9-1.2 (Omi et al., 2013; Toda and Stein, 2013). However, it is clear that $b$-values can vary in space and time (Wiemer and Wyss, 2002).

In view of the variations observed in well-instrumented regions, along with the requirement of a large number of data points to constrain $b$-values (2000 earthquakes are needed to calculate $b$ to within 0.05 at the $98 \%$ confidence level; Felzer, 2006), constraining $b$-values in areas with sparse data (which can happen if the area is small or seismicity is low) is a challenge. In this study, we assume a $b$-value of $1 \pm 0.025$ at 1- $\sigma$ confidence levels for all areas studied. The uncertainty on the $b$-value is assumed to be Gaussian. This could easily be altered if different $b$-values were assessed to be more appropriate.

\section{Aftershocks}

For each study area, we built a seismicity model using the existing seismicity data, assuming a generic $b$-value of $1 \pm 0.025$. We added large events and their aftershocks as needed to balance the moment budget, but with the condition that the resulting seismicity model followed the GR distribution with the prescribed $b$-value. We simulated aftershocks, assuming that individual sequences followed the GR distribution with the prescribed $b$-value and also followed the Båth's law (Båth, 1965), with the largest aftershock being $1.2 \pm 0.1$ below the mainshock. The Båth's law emerges naturally if aftershock catalogs are generated using a stochastic procedure (Helmstetter and Sornette, 2003), but we actually have to enforce it in this case, as we do not use a stochastic procedure to model aftershocks. The value of 1.2 is the global average (Båth, 1965) and relates to the average aftershock productivity, which varies. For California, the average largest aftershock was found to be 1.16 below the mainshock for earthquakes over $M_{\mathrm{w}} 5.5$ (Shcherbakov and Turcotte, 2004). For example, if we were to add a magnitude of 8 to the record, we would assume an aftershock sequence with the largest aftershock being 6.8, and then smaller earthquakes with frequencies in accordance with the GR. If an earthquake with a magnitude of 8 occurred once every 100 years, this aftershock sequence would also occur every 100 years. This is similar to other studies that modeled the number of aftershocks above a given magnitude cutoff as $10^{\alpha M}$, in which $M$ is the mainshock magnitude and $\alpha$ is a parameter to be determined. In our model, $\alpha$ is the same as the $b$-value; this means it is about 1, as it has been in other studies (Felzer et al., 2004; Helmstetter et al., 2005). It would be possible to use a different aftershock distribution model or a stochastic procedure to generate aftershock sequences, as can be done with the epidemic-type aftershock sequence (ETAS) 


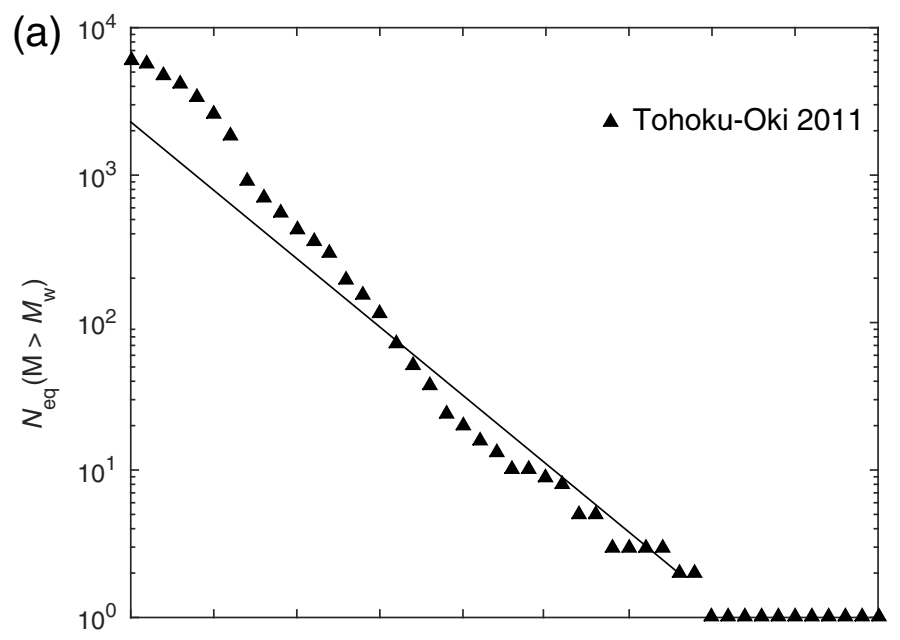

(b)
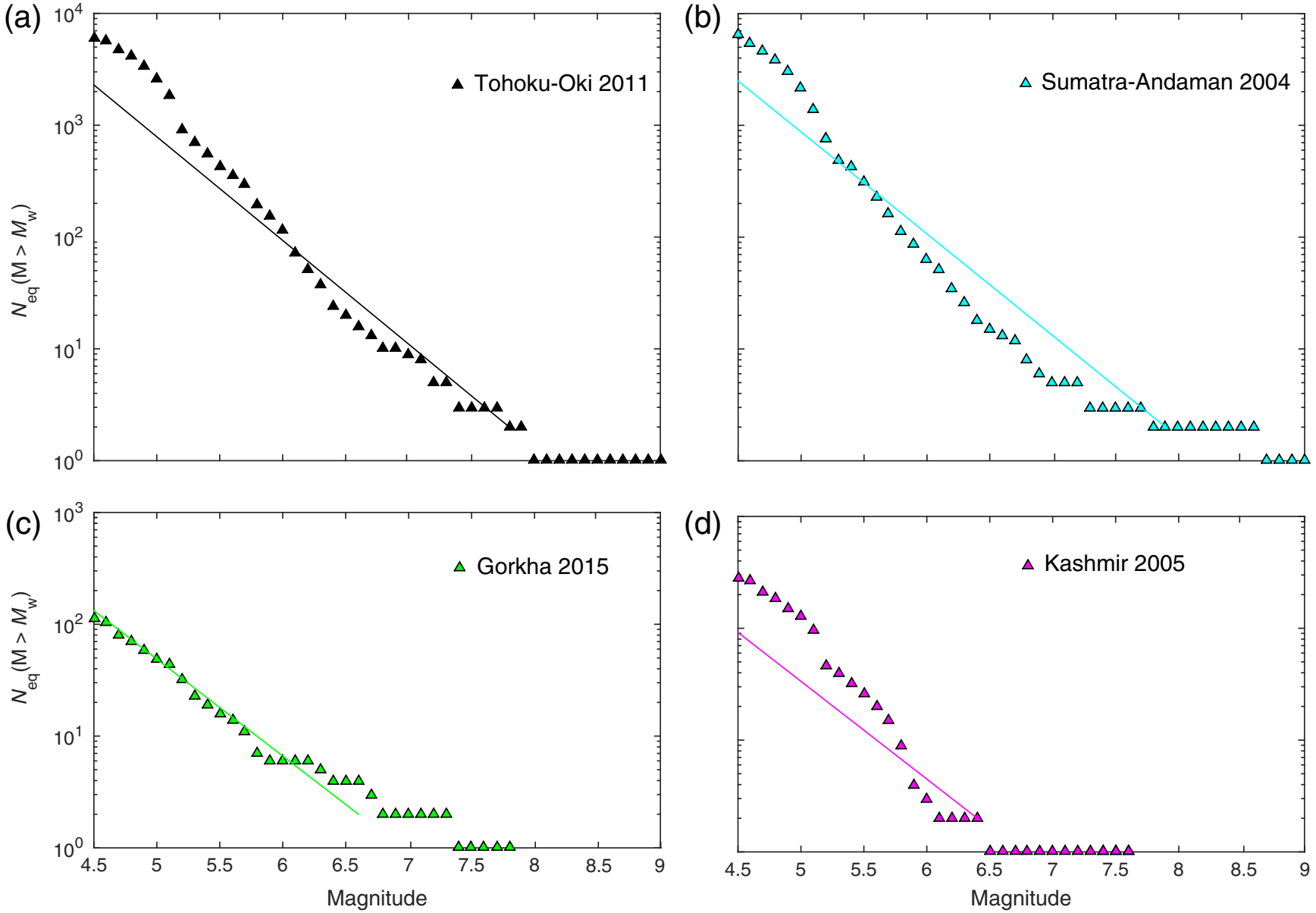

(d)

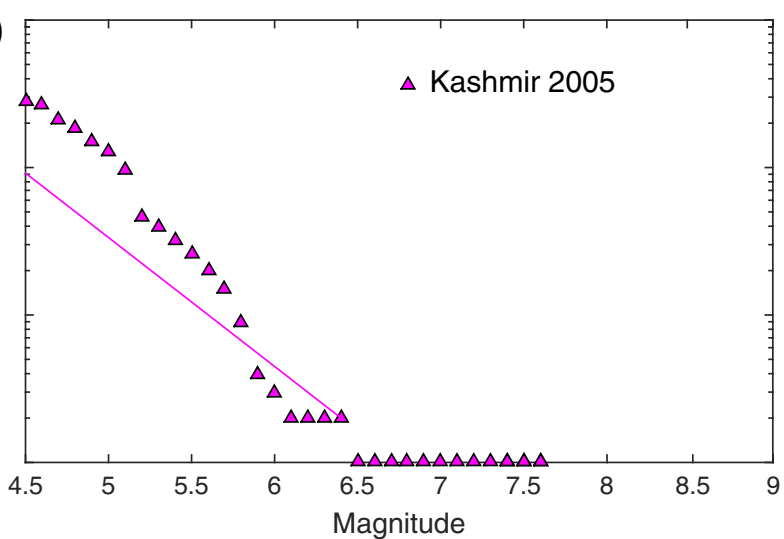

Figure 2. Instrumentally recorded aftershocks versus aftershocks from model. In the aftershock models, the $b$-value is 1 , and the maximum aftershock is 1.2 below the mainshock (Båth, 1965). (a) $2011 M_{\mathrm{w}} 9.0$ Tohoku-Oki, (b) $2004 M_{\mathrm{w}} 9.1$ Sumatra-Andaman, (c) 2015 $M_{\mathrm{w}} 7.8$ Gorkha, and (d) $2005 M_{\mathrm{w}} 7.6 \mathrm{Kashmir}$. The color version of this figure is available only in the electronic edition.

model (Ogata, 1988). ETAS models require various parameters to be known beforehand, which makes these models difficult to apply in areas of sparse data. The total number of aftershocks obtained with our approach is the same as in the self-similar earthquake triggering model of Shearer (2012), given the parameters he used to fit Båth's law ( $m_{2}=7, m_{1}=0, r=0.5$, and $\left.b=1\right)$, so using a stochastic model of aftershocks would not affect the moment budget.

Although our aftershock model is generic, it compares favorably with aftershocks observed in case examples (see Fig. 2). For Tohoku-Oki 2011, the largest aftershock was 1.1 magnitude units below, and the $b$-value was $0.9-1.2$ (Omi et al., 2013; Toda and Stein, 2013). For Gorkha 2015, the first aftershock sequence had the largest aftershock being 1.1 magnitude unit below the mainshock, whereas the second larger aftershock was only 0.5 magnitude units below the mainshock magnitude. The $b$-value for this aftershock sequence (using the maximum-likelihood method; Aki, 1965; Utsu, 1965) was found to be 1.08. About 31 earthquakes occurred where $M_{\mathrm{w}}>5$ and $105 M_{\mathrm{w}}>4.5$, whereas the model here would produce 43 and 142, respectively. For the Kashmir 2005 earthquake, the largest earthquake was 1.2 magnitude units below, and the aftershock catalog had a $b$-value of $1.09 \pm 0.07$, as found by Tahir and Grasso (2014). Here, the aftershock rate was high, and 48 earthquakes occurred with $M_{\mathrm{w}}>5$ and $198 M_{\mathrm{w}}>4.5$, whereas the model we use here would produce 27 and 90 , respectively.

\section{Data}

In all of our examples, we use the U.S. Geological Survey instrumental global catalog from 1996 to the present, giving us 20 years of data (see Data and Resources). This catalog and this time period gives us a relatively homogeneous data set and is complete, down to the fairly low magnitudes of around 4-5. The studied areas need to be large enough that GR is fulfilled, and that the earthquake rates are approximately constant over the time interval covered by the seismicity data (20 years of instrumental seismicity). The model is concerned only with the average properties within the study area. It is therefore more relevant to consider zones with a priori relatively homogeneous properties. In practice, we consider well-known faults in their entirety, and for continental strike-slip faults, we take instrumental seismicity 
within $10 \mathrm{~km}$ of the fault. We thus assume that the near-fault seismicity and the major earthquakes on these faults are part of one earthquake population that follows the GR law overall. For the Kunlun and Boconó faults, where the traces are less well known and errors in epicentral locations are greater, we use a wider swath of $20 \mathrm{~km}$. For subduction zones, we take instrumental seismicity within the width of the seismogenic zone without taking the earthquake depths into account, as these depths can introduce large errors. We realize that this selection could include plate-bending earthquakes above the dipping slab, though we assume they only make up a small fraction of the total.

We want instrumental catalogs representative of the interseismic period. In some cases, recent large earthquakes are included in the seismicity catalog, and their aftershocks compose a significant fraction of the earthquake catalog. In such cases, we either remove the large earthquakes and their aftershocks or cut the catalog at the time of the mainshock if aftershocks overwhelm all the subsequent data. For example, the $2015 M_{\mathrm{w}} 7.8$ Gorkha earthquake and its aftershocks were removed using the Reasenberg declustering (Reasenberg and Jones, 1989), whereas for the $2011 M_{\mathrm{w}} 9$ Tohoku-Oki earthquake, we cut the catalog just before the main event.

Model Steps: "Filling in" the Earthquake Catalog to Find Average Activity Rate

Here, we detail the iterative procedure used to estimate $M_{\max }$. We assume Gaussian uncertainties for $b$, seismogenic depth, and cutoff magnitude $\left(M_{\mathrm{c}}\right)$ values, whereas we use a uniform distribution for the fraction of moment released aseismically (between $0 \%$ and $20 \%$ ).

We show an example of the method for the San Andreas fault system (SAFS) in Figure 1. This system has had no earthquakes larger than $M_{\mathrm{w}} 6$ in the study period. It can be seen that a line that directly extrapolates the instrumental data (having assumed GR, with a $b$-value of around 1) would intersect with the line representing the moment budget closure at around $M_{\mathrm{w}} 9$. As mentioned earlier, this intersection does not yield $M_{\max }$ because the seismicity model corresponding to the extrapolated GR law is missing all the aftershocks from the events with magnitudes larger than the maximum observed event. The iterative procedure below yields a seismicity model that includes larger earthquakes not recorded in instrumental time and all of their aftershocks, while still remaining consistent with the instrumental data.

1. In the first step, we try a maximum magnitude that is larger than we expect the answer to be; for example, a magnitude derived from the simple extrapolation of the GR distribution obtained from the instrumental seismicity. In Figure 1b,c, we show the example where we have initially chosen an $M_{\max }$ of 9 . We initially find the rate at the cutoff magnitude (found using the maximum curvature method, implemented using ZMAP; Wiemer, 2001) to extrapolate the instrumental data according to the GR law, and add on the number of missing $M_{\mathrm{w}} 9$ earthquakes that it suggests. We then also add on the modeled aftershocks. This increases the average rate of smaller earthquakes, which raises the entire instrumental catalog slightly. We then extrapolate again from this new slightly raised catalog to find the number of missing $M_{\mathrm{w}} 8.9$ earthquakes (fewer iterations would be needed with a smaller step size, but the results would converge to the same value). Again, we add their aftershocks, which again raises the instrumental catalog. We repeat this process going down in steps of 0.1 until the cutoff magnitude, in this case $M_{\mathrm{w}}$ 4.4. This process is shown in Figure 1b.

2. Now we add earthquakes from $M_{\mathrm{w}} 9$ to 4.4 . The seismicity rates in the range of magnitudes of the instrumental catalog have been shifted upward, and we realize that we added on too few $M_{\mathrm{w}} 9$ earthquakes for what the extrapolation of the seismicity in this magnitude range would now predict. This can be seen from the difference between the highest dark line (old extrapolation) and the lighter lines (new extrapolation) in Figure 1c. Therefore, we repeat the entire process again with two additional repetitions, as shown in Figure 1c. The adjustments needed in each loop become smaller and smaller until the addition is minimal.

3. After steps 1 and 2, we find that we have a seismicity model which represents the long-term averaged behavior (over a time much longer than the return period of $M_{\max }$ ), with a maximum magnitude of 9 . However, this extrapolated line intersects the maximum earthquake line at $M_{\mathrm{w}} 8.0$, suggesting that there is no need of larger events to balance the moment budget. This is therefore inconsistent with the model having $M_{\max } 9$, so we have to lower the initial trial guess. When we do this, the final predicted maximum earthquake becomes slightly higher because there are now fewer earthquakes that are factored into the calculation. We decrease our guessed value until it matches the value needed to close the moment budget. This is shown in Figure 1d, where our initial maximum magnitude was guessed at 8.1 , and the predicted maximum magnitude is also 8.1 .

This procedure ensures consistency between the interseismic seismicity, estimated from the instrumental catalog, and the long-term seismicity model. However, there is no assurance that the observed seismicity is a likely realization of this model. This can be verified a posteriori by generating random catalogs of duration equal to those covered by the observations. In this particular example involving the SAFS, the magnitude-frequency distribution of observed seismicity falls well within the population of distributions predicted by the model and therefore is a likely realization of the model (see Fig. 3).

\section{Results}

\section{San Andreas Fault System}

We assume a velocity on the fault of $30 \pm 5 \mathrm{~mm} / \mathrm{yr}$ at the $1-\sigma$ level, which represents an average of the net dextral 


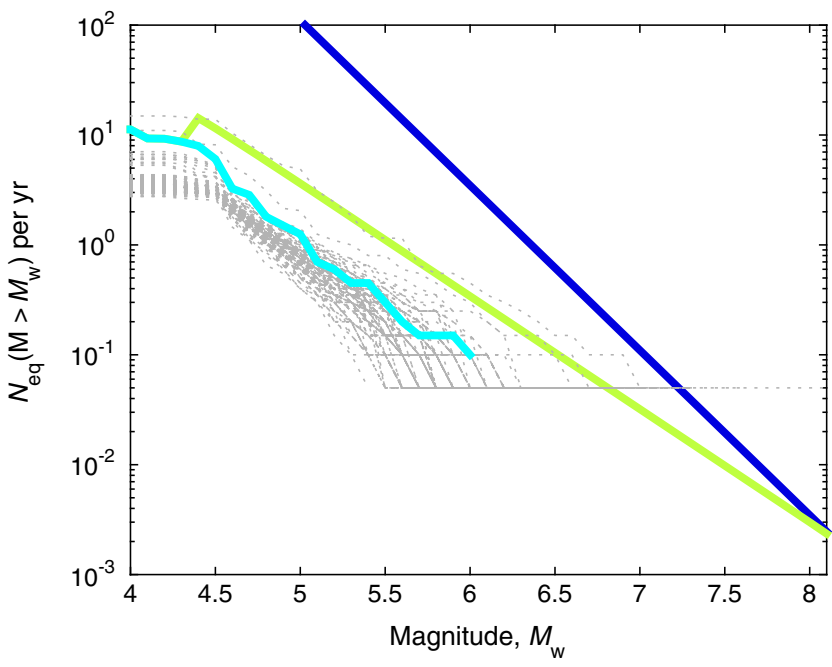

Figure 3. Comparing instrumental data (lower line) with 100 realizations of 20 years of data with the same statistics as the mainshocks in the final average catalog test, shown as dotted lines. These different realizations have varying maximum-sized earthquakes, from 5.3 to 8.2 in the cases shown here. The color version of this figure is available only in the electronic edition.

slip rate across the fault system within the latitudes studied, from $32.6^{\circ} \mathrm{N}$ to $39.6^{\circ} \mathrm{N}$ (e.g., Meade and Hager, 2005). The coupled width is very close to the default value of $12.5 \pm 2.5 \mathrm{~km}$ (Meade and Hager, 2005; Smith-Konter et al., 2011), so we use the default value. This yields an average moment deficit buildup rate of $(6.6 \pm 1.8) \times 10^{18} \mathrm{~N} \cdot \mathrm{m} / \mathrm{yr}$, or roughly $1.2 \mathrm{~N} \cdot \mathrm{m} / \mathrm{yr} / \mathrm{km}$. This falls within the range of values found by Smith-Konter et al. (2011) which can vary from $1.5-1.8 \mathrm{~N} \cdot \mathrm{m} / \mathrm{yr} / \mathrm{km}$ on the faster segments to $0.2 \mathrm{~N} \cdot \mathrm{m} / \mathrm{yr} / \mathrm{km}$ on the slower segments of the SAFS.
Though there are some variations, $b$-values from different studies average around 1 in California for both the instrumental and historical records (Felzer, 2008; Wang et al., 2009; Hutton et al., 2010). We compare the results with historical earthquakes (Stover and Coffman, 1993; National Geophysical Data Center [NGDC], 2016) within $20 \mathrm{~km}$ of the fault trace (wider than the $10 \mathrm{~km}$ we use for the recent instrumental data to allow for larger location errors in the historical catalog), as shown in Figure 4. For this figure, we plot the frequency of $M_{\mathrm{w}} \geq 7$ since $1800, M_{\mathrm{w}} \geq 5.5$ since 1850 , and $M_{\mathrm{w}} \geq 4.5$ since 1950 , which corresponds to the magnitude of completion in these different time periods.

With these assumptions, we find that the maximum magnitude earthquake would be $M_{\mathrm{w}} 8.1 \pm 0.3$ at the $1-\sigma$ confidence level, with a recurrence time of 380 years. The lower estimate would be 210 years, and the upper estimate would be 950 years. The largest reliably known earthquake is the $1857 M_{\mathrm{w}} 7.9$ Fort Tejon, which ruptured roughly $350 \mathrm{~km}$ of the SAFS. Previous estimates of $M_{\max }$ are similar to that estimated here, from $M_{\mathrm{w}} 8$ (Field et al., 1999, using a characteristic earthquake model and conservation of moment) to $8.3 \pm 0.4$ (Kijko, 2004, using statistics of the earthquake catalog). Paleoseismic data recurrence intervals from different segments vary from $88 \pm 41$ yrs for magnitudes 6.5-7.9 in the Carizo Plain (Akçiz et al., 2010), to roughly 70 years at the Wrightwood paleoseismic site with estimated magnitudes of 6.8-7.9 (Scharer et al., 2010). Field et al. (1999) predict that an earthquake of magnitude $M_{\mathrm{w}}>7.8$ will occur every 334 years on average in southern California. According to the Uniform California Earthquake Rupture Forecast, v. 3 (Field et al., 2014), an earthquake of $M_{\mathrm{w}} 8.25$ is feasible every 1000 years. For comparison with these estimates, our model would predict an earthquake above 6.5 roughly once
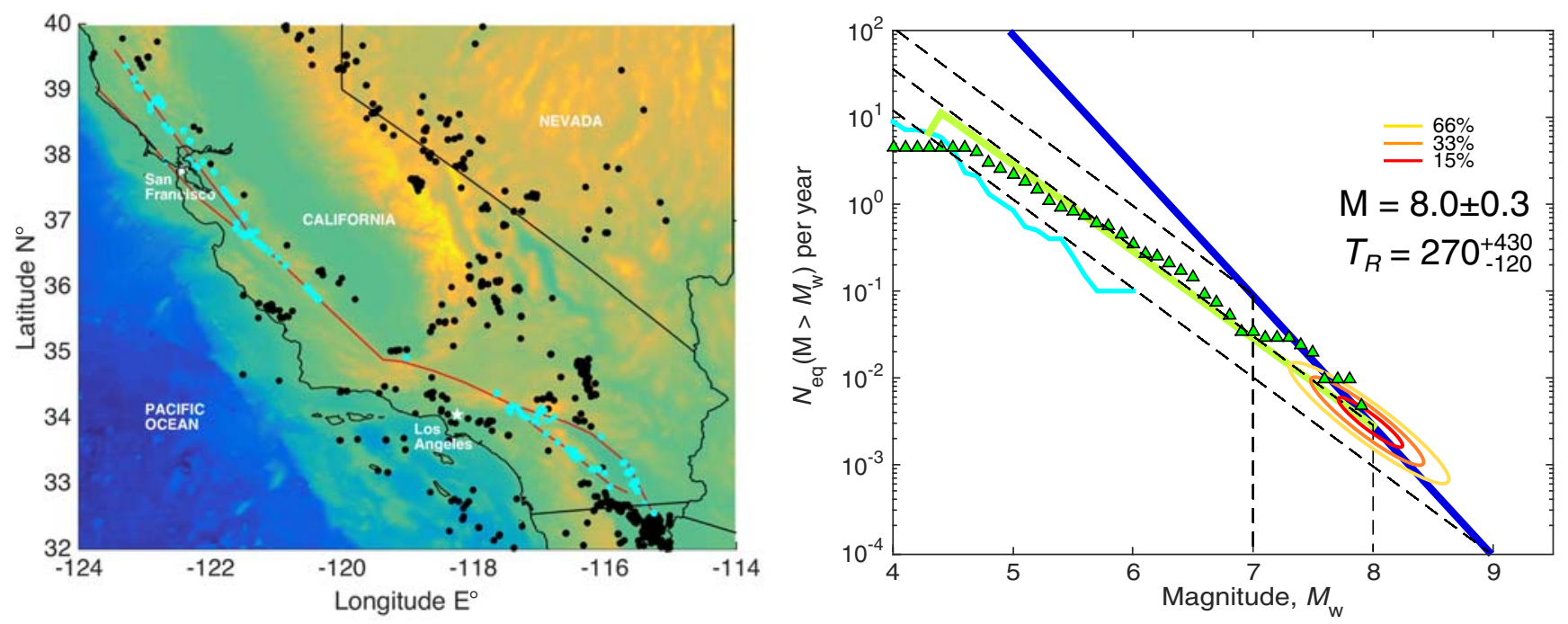

Figure 4. Results of the model for the SAFS. The thick upper straight line shows the frequency of the maximum magnitude earthquake that would need to occur to take up all the moment buildup. The probabilities of being within the different ovals are shown, taking into account the uncertainties on the $b$-value, the moment buildup rate, and the value of the largest aftershock. Here, the straight line shows the final averaged modeled catalog. The triangles show the historical data. The left panel shows the fault line with the earthquakes as black dots and the earthquakes selected to use in the model as lighter dots. The color version of this figure is available only in the electronic edition. 

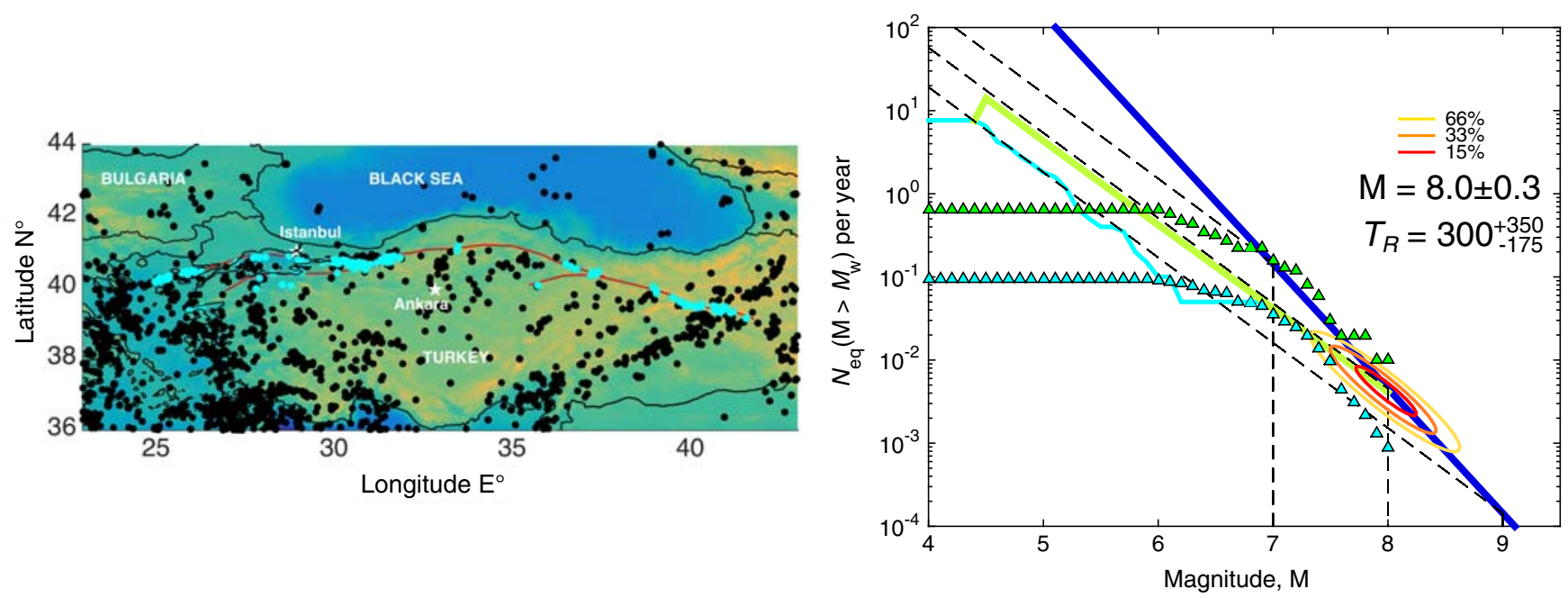

Figure 5. Results of the model for the North Anatolian fault. The upper triangles show the historical data averaged over the past 100 years, whereas the lower triangles represent the averages over the past 2300 years. The color version of this figure is available only in the electronic edition.

every 10-20 years and an earthquake above 7.8 roughly once every 190-220 years for the entire length of the SAFS. This example shows that our method, which relies only on the recent instrumental seismicity and the moment budget balance, yields seismicity rates and $M_{\max }$ values that are very consistent with the historical and paleoseismological information available for this fault.

\section{North Anatolian Fault}

The North Anatolian fault is $\sim 1200 \mathrm{~km}$ long, striking roughly east-west from eastern Turkey to the north Aegean. Slip rates vary from $20 \mathrm{~mm} / \mathrm{yr}$ in the east to $25 \mathrm{~mm} / \mathrm{yr}$ in the west (Şengör et al., 2005; Kozaci et al., 2007). We use a slip rate of $22 \pm 3 \mathrm{~mm} / \mathrm{yr}$ and the default coupled width of $12.5 \pm 2.5 \mathrm{~km}$, similar to values found geodetically (Reilinger et al., 2006; Hussain et al., 2016), in order to calculate the seismic moment buildup. We remove the $1999 M_{\mathrm{w}} 7.6$ İzmit earthquake and aftershocks from our catalog, and we are left with 82 earthquakes above the cutoff magnitude (found to be $M_{\mathrm{w}}$ 4.5). We compare the results with historical data from the past 2300 years, considered complete to $M_{\mathrm{w}} \geq 7.4$ by the catalog compilers (Bohnhoff et al., 2016).

The model yields $M_{\max }$ of $8.0 \pm 0.3$ with a recurrence time of 275 years; the lower estimate is 135 years, and the upper estimate is 650 years. The maximum historical earthquake with a reliable magnitude was $M_{\mathrm{w}} 7.8$ in 1939. Previous estimates of $M_{\max }$ are in the $M_{\mathrm{w}}$ 7.9-8.1 range (Bohnhoff et al., 2016). Estimates of interevent times for paleoseismic earthquakes vary widely; some estimate 210-280 years (Klinger et al., 2003), while others estimate 200-900 years (Hartleb et al., 2006). There seems to have been a cluster of earthquakes $M_{\mathrm{w}}>6.7$ in the past century, and there are suggestions of similar sequences in the seventeenth to eighteenth centuries and tenth to twelfth centuries (Hartleb et al.,
2006). This variable rate can be seen in Figure 5 and shows both the paleoseismic record over the past 2300 years and the record for the past 100 years (Bohnhoff et al., 2016). The record in the past 100 years is probably higher than average due to clustering, although it is also possible that the record over the past 2300 years may be lower due to missing events; events become harder to detect as we go further back in time, when the magnitude is harder to estimate. For example, there were apparently only 5 earthquakes $>7.5$ recorded between 300 B.C. and A.D. 1000, but then 17 from 1000 to present, with at least 3 for every 200 years, compared to periods of more than 200 years with no $M_{\mathrm{w}}>7.5$ earthquakes that were recorded further back in time. Bearing in mind the high temporal variability in the paleoseismic record and potential for incompleteness, our model does not disagree with these data.

\section{Main Himalayan Thrust}

The Main Himalayan thrust is an 2000-km-long continental thrust fault along which the Indian plate is thrust beneath the Himalaya. It has produced large earthquakes in the past and poses a large threat to densely populated areas. We use a moment buildup rate of $15.1 \pm 1 \times 10^{19} \mathrm{~N} \cdot \mathrm{m} / \mathrm{yr}$ (Stevens and Avouac, 2015) and allow 33\% of the moment to be released nonseismically (by afterslip), following Stevens and Avouac (2016). We take into account earthquakes that occur up to $150 \mathrm{~km}$ north perpendicular to the surface trace of the Main Frontal thrust, and we have excluded the 25 April 2015 Gorkha earthquake and its aftershocks. Figure 6 shows the results and a comparison with the historical and paleoseismic record for the past 1000 years, summarized by Stevens and Avouac (2016).

We get a mean $M_{\max }$ of 9 and an uncertainty of 0.2 . The mean recurrence time would be 1200 years, with a variation from 550 to 2700 years (Fig. 6). This finding is consistent 

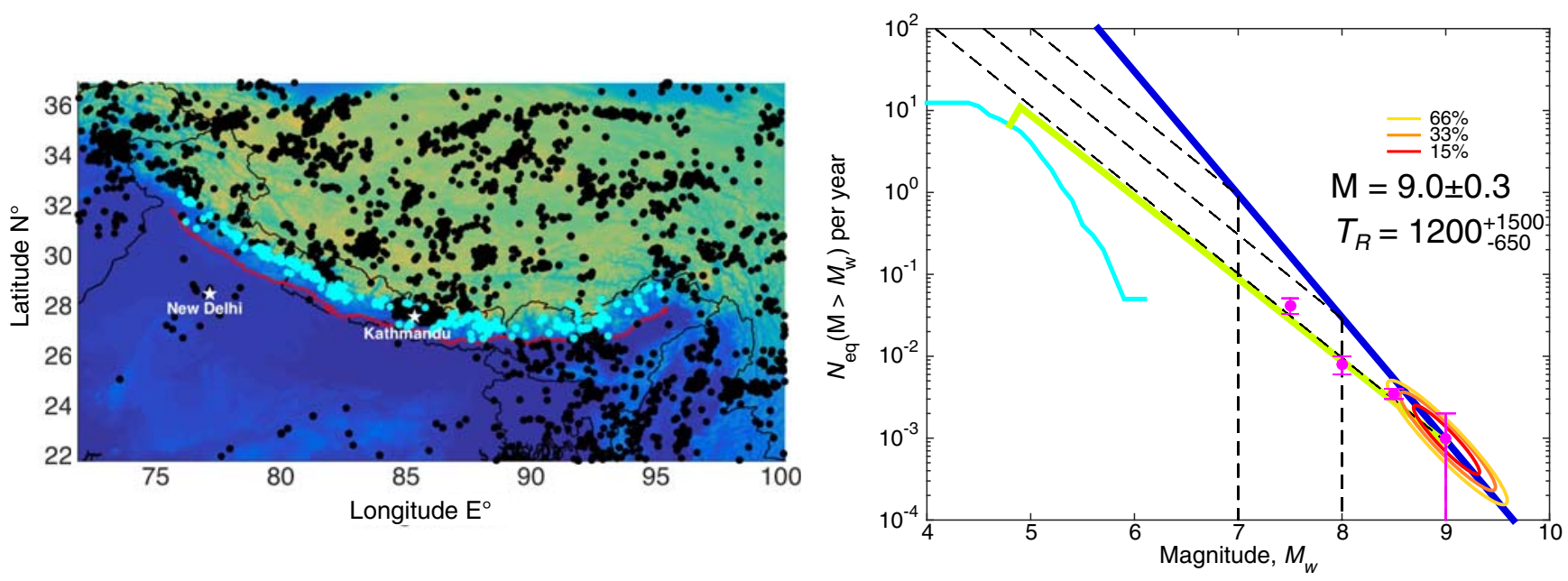

Figure 6. Results of the model for the Main Frontal thrust with dots and error bars showing the historical and paleoseismic data. The color version of this figure is available only in the electronic edition.

with the reporting of large paleoseismic events of magnitudes potentially up to $M_{\mathrm{w}} 9$ (e.g., Upreti et al., 2000; Lavé et al., 2005; Kumar et al., 2010). Our method yields a $66 \%$ chance that $M_{\max }$ has to be over $M_{\mathrm{w}} 8.7$ (the largest historical earthquake) and about a $95 \%$ chance that it has to be more than $M_{\mathrm{w}} 8.5$ and less than $M_{\mathrm{w}} 9.5$. For comparison, Stevens and Avouac (2016), who carried out a similar analysis with the addition of historical and paleoseismic data, assess there to be a $66 \%$ chance that $M_{\max }$ has to be 9 or over, higher than $M_{\mathrm{w}} 8.7$ here. Uncertainties in the $b$-value lead to uncertainties that will be larger as the predicted $M_{\max }$ becomes larger, because this means that the data have to be extrapolated further. The extrapolation processes from historical and paleoseismic earthquakes suffer less from $b$-value uncertainties, but the uncertainty in the rates then becomes much higher.

\section{Japan Trench}

The Japan trench, located off of the northeast coast of Japan, is a fast-converging plate boundary, where the Pacific subducts beneath the Okhotsk plate. The subduction zone produces frequent large earthquakes of $M_{\mathrm{w}} \sim 7.5$, as well as infrequent giant earthquakes, such as the 11 March $2011 M_{\mathrm{w}} 9$ Tohoku-Oki earthquake (e.g., Hashimoto et al., 2009; Ozawa et al., 2011). We use a mean slip rate of $80 \pm 8 \mathrm{~mm} / \mathrm{yr}$ (Loveless and Meade, 2010), an average dip of $13^{\circ}$, and a seismogenic depth of $35 \pm 5 \mathrm{~km}$ (Zhan et al., 2012) to calculate the moment buildup rate. We select instrumental earthquakes on the down-dip side, within $250 \mathrm{~km}$ of the fault trace (about $50 \mathrm{~km}$ longer than the distance used for the moment calculation). We only use the catalog before the Tohoku-Oki $M_{\mathrm{w}} 9$ earthquake, as this completely contaminates the catalog with aftershocks. We also remove the $M_{\mathrm{w}} 8.3$ Hokkaido event of 2003 and its aftershocks. With a dip of $13^{\circ}$ and seismogenic depth of $35 \pm 5 \mathrm{~km}$, the interface is coupled to within about $200 \mathrm{~km}$ of the trench, which agrees with the limits of the aftershock distribution after the Tohoku-Oki earthquake (Shino- hara et al., 2013). As with other subduction zones, we initially take the coupled fraction to be $45 \%$. We show the results and a comparison with the historical record dating back to 1850 (Usami, 2002) in Figure 7.

Our mean $M_{\max }$ is 9.3 with $1-\sigma$ error of 0.3 . The mean repeat time is 520 years, with a lower bound of 220 years and upper bound of 1200 years. The largest earthquake of which we are aware that took place in this location is the $2011 M_{\mathrm{w}} 9$ Tohoku-Oki event, so here we have a high lower bound for $M_{\max }$. Previous estimates for $M_{\max }$ varied from 9 (McCaffrey, 2008, using scaling relations and fault segment lengths) to 10 (if confidence limits are high) (Zöller et al., 2014, using the tapered GR distribution, but not conservation of moment). Using the theory of extreme values, Pisarenko et al. (2010) found the absolute $M_{\max }$ to be $9.57 \pm 0.86$ for Japan. With the model and assumptions here, there is a $30 \%$ chance that $M_{\mathrm{w}} \leq 9$ could be $M_{\max }$, but almost zero chance that it would be as large as $M_{\mathrm{w}} 10$.

Previous estimates of recurrence times based on either conservation of moment suggested for the largest events are 532 years (McCaffrey, 2008), 260-280 years (Uchida and Matsuzawa, 2011), 300-400 years (based on the historical record) (Kagan and Jackson, 2013), and 600 years for the Tohoku-Oku area (Satake, 2015). The last agreed upon event that had a magnitude similar to Tohoku-Oki is the A.D. 896 event (Minoura et al., 2001), identified by tsunami deposits. At least two more large tsunami deposits have been found in this area in the past 3000 years, suggesting a recurrence time of around 1000 years. Others, however, have suggested that other past earthquakes were also as large as Tohoku-Oki; one example is the 1611 Keicho earthquake. In the Kuril trench just northeast of Japan, with a similar tectonic setting, tsunami-causing earthquakes have occurred in the past 2000-7000 years, with a rough recurrence time of 500 years (Nanayama et al., 2003). However, some recordings of tsunamis may come from far-field events such as earthquakes in 

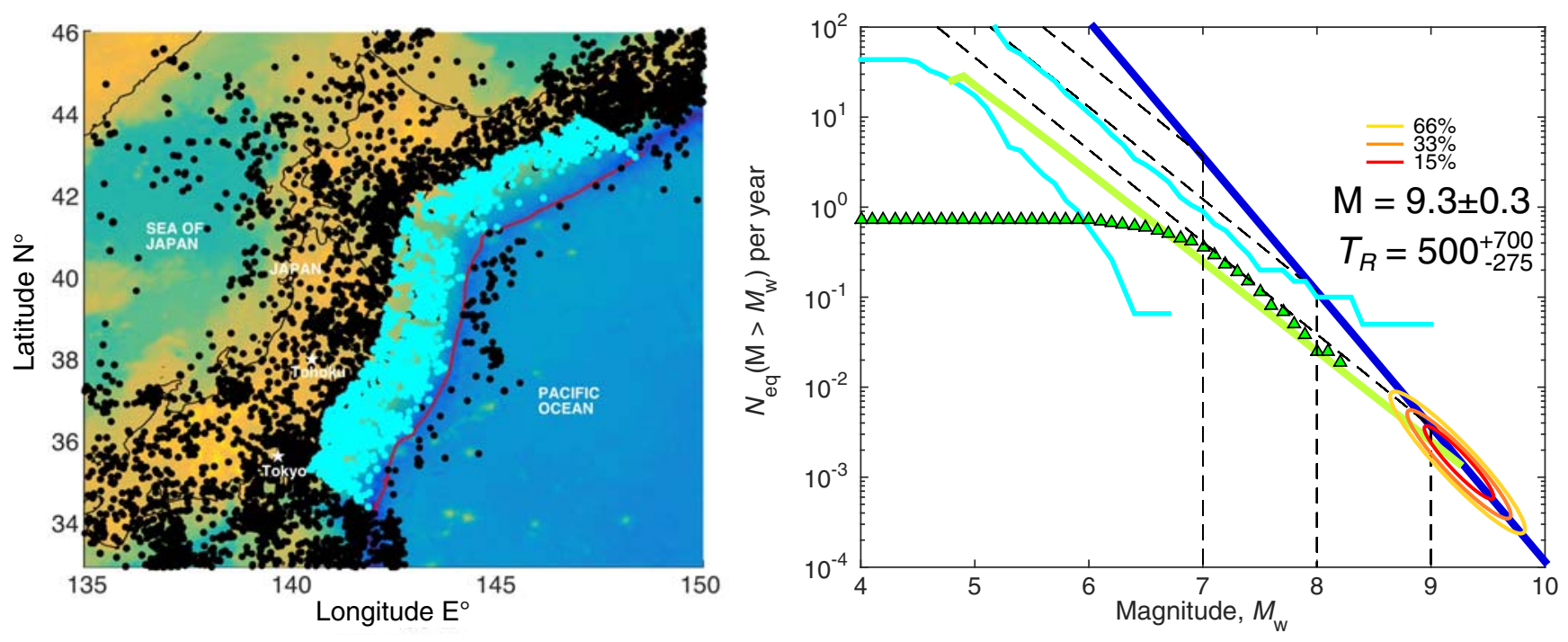

Figure 7. Results of the model for the Japan trench, with triangles showing the historical data. The two thin lines show the instrumental data prior to (lower) and including (higher) the Tohoku-Oki earthquake. The color version of this figure is available only in the electronic edition.

Chile (Ishimura and Miyauchi, 2015). These paleoseismic data do not disagree with the $M_{\max }$ of 9.3 and repeat time of 520 years for the entire Japan trench. The modeled catalog agrees quite well with the historical record, where recurrence times are 3 years for $M_{\mathrm{w}}>7$ and 40 years for $M_{\mathrm{w}}>8$. According to the results obtained using the model, recurrence times would be 4 years for $M_{\mathrm{w}}>7$ and 40 years for $M_{\mathrm{w}}>8$.

The ability of earthquake rates to change drastically can be seen by comparing the average instrumental catalog before the 2011 earthquake to the average catalog including the 2011 earthquake and its aftershock. These two lines can be seen in Figure 7. Including the full catalog, we have a repeat time for earthquakes $M_{\mathrm{w}}>8$ of 10 years, as opposed to 40 years beforehand, and on average 250 earthquakes $M_{\mathrm{w}}>5$ per year compared to only 20 beforehand. This shows that the instrumental catalog we have could be a lot lower than the average if there were no large events included, which is quite likely.

Coupling is the largest unknown here, with variations along the Japan trench falling between close to $0 \%$ and 80\% (Uchida and Matsuzawa, 2011; Loveless and Meade, 2015). The average coupling is somewhere in between. We initially assumed an average coupling of $45 \%$. This unknown fraction of seismic buildup is a greater problem for subduction zones, which have very variable coupling, than it is for continental strike-slip faults where the coupling is generally much higher and more consistent along the strike (although there are some variations). If instead of fixing the fraction of coupling, we fix the largest magnitude at $M_{\mathrm{w}} 9$, we could potentially work out the amount of aseismic release that would correspond to this. We initially assumed that coupling was on average $45 \%$, but we would need a coupling of $30 \%$ for a magnitude of 9 to be the average maximum magnitude, which would give a repeat time of 400 years.

\section{Sumatra-Andaman Trench}

The Sumatra-Andaman megathrust extends between $10^{\circ} \mathrm{S}$ and $15^{\circ} \mathrm{N}$, where the Indo-Australian plate subducts beneath the Sunda plate. We use a mean slip rate of $50 \pm 10 \mathrm{~mm} / \mathrm{yr}$ (Sieh and Natawidjaja, 2000; Chlieh et al., 2008), an average dip of $13^{\circ}$, and a seismogenic depth of $45 \pm 5 \mathrm{~km}$ (Chlieh et al., 2008). We select instrumental earthquakes on the down-dip side, within $250 \mathrm{~km}$ of the fault trace (about $75 \mathrm{~km}$ longer than the distance used for the moment calculation). We only use the catalog before the 2004 Sumatra-Andaman earthquake, as after this the catalog is contaminated with many aftershocks. We also remove the $M_{\mathrm{w}} 7.9$ event of 2000 and its aftershocks. We initially take the coupling fraction to be $45 \%$. We show the results in Figure 8 and a comparison with the historical record since 1797 (Chlieh et al., 2008, and references within).

Our mean $M_{\max }$ is 9.0 with $1-\sigma$ error of 0.3 . The mean repeat time is 200 years, with a lower bound of 80 years and upper bound of 450 years. The largest earthquake to have occurred on the trench is the recent $2004 M_{\mathrm{w}} 9.1-9.2$ event (Lay et al., 2005; Chlieh et al., 2007), so as is the case with the Japan trench, we have a high lower bound for $M_{\max }$. Our model has a mean maximum earthquake that is slightly lower in magnitude than the largest earthquake here. One reason for this could be that our simplified model of moment buildup has large errors, and we do not know the coupling well; however, our estimate of $45 \%$ lies somewhere in the middle of the values Chlieh et al. (2008) found from paleogeodetic and geodetic data. They used a value of rigidity of $64 \mathrm{GPa}$, whereas we used $50 \mathrm{GPa}$. They calculate the moment buildup to be $4-6 \times 10^{20} \mathrm{~N} \cdot \mathrm{m} / \mathrm{yr}$ over $8^{\circ}$ of latitude $\left(2^{\circ} \mathrm{N}-6^{\circ} \mathrm{S}\right)$, about a third of the area we studied $\left(10^{\circ} \mathrm{S}\right.$ and $15^{\circ} \mathrm{N}$ ), over which we have an average moment buildup rate 

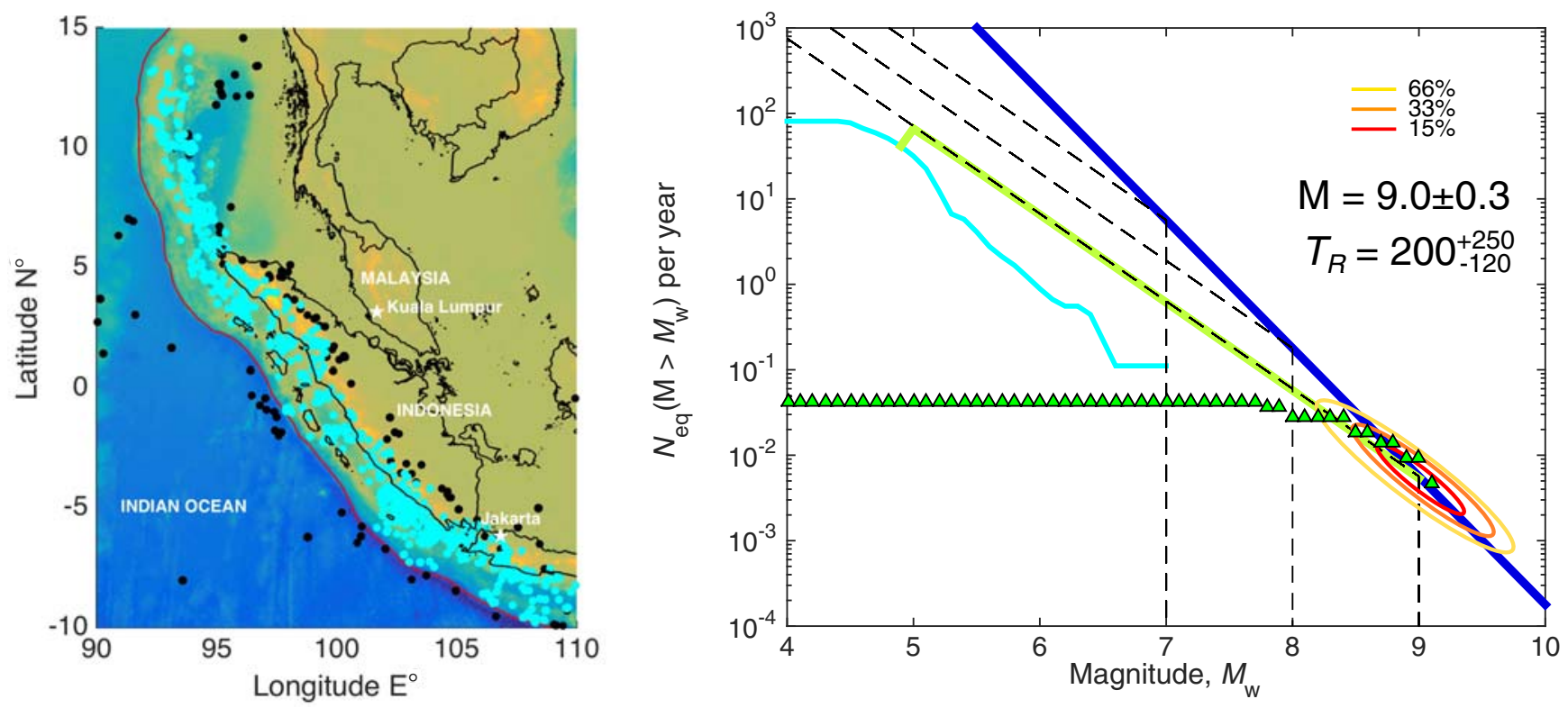

Figure 8. Results of the model for the Sumatra-Andaman trench, with triangles showing the historical data. The color version of this figure is available only in the electronic edition.

of only $5 \times 10^{20} \mathrm{~N} \cdot \mathrm{m} / \mathrm{yr}$. If we were to double the moment buildup by increasing the rigidity and fraction coupled, this would increase the modeled mean maximum magnitude to $M_{\mathrm{w}}$ 9.5. In the rupture area of the 2004 event, previously known earthquakes had reached only up to $M_{\mathrm{w}} 7.9$ in size (Bilham et al., 2005).

\section{Cascadia Subduction Zone}

The Cascadia subduction zone (CSZ), from northern California to Vancouver Island, is a convergent plate boundary that is known for its recent quiescence, as well as its tremor and slow slip (e.g., Schwartz and Rokosky, 2007; Kao et al., 2010; Wech and Bartlow, 2014). The largest recorded earthquake in instrumental records is the 1992 $M_{\mathrm{w}}$ 7.1 Cape Mendocino event (Oppenheimer et al., 1993); there are very few other earthquakes here on record that were even medium-sized. In our analysis, we use a convergence rate of $40 \pm 5 \mathrm{~mm} / \mathrm{yr}$ (Wilson, 1993; Wech and Creager, 2011) and a dip of $10^{\circ}$ (Savage et al., 1991; Rong et al., 2014). The vertical extent of the seismogenic zone has been debated, from $15 \mathrm{~km}$ (Dragert et al., 1994) to $20-30 \mathrm{~km}$ (Williams et al., 2011; Hyndman, 2013; Rong et al., 2014); here we take a value of $25 \pm 10 \mathrm{~km}$, giving an average seismogenic width of $125-150 \mathrm{~km}$. We select instrumental earthquakes on the down-dip side, and as with other subduction zones, we take the coupled fraction to be $45 \%$.

Because of the remarkably quiet seismic activity in view of the relatively rapid rate of accumulation of moment deficit, our analysis implies vary large infrequent earthquakes (Fig. 9). This inference is consistent with the evidence that this subduction zone generated giant tsunamigenic earthquakes in the past, the most recent being an $M_{\mathrm{w}} \sim 9$ event in A.D. 1700; this earthquake had a magnitude of roughly 9 (Satake et al., 2003). However, our model yields an implausible maximum magnitude $M_{\max }$ of 10.8 with a mean repeat time of about 700,000 years. The physical $M_{\max }$ for the CSZ, with a length of roughly $1000 \mathrm{~km}$, rupture width of up to $125 \mathrm{~km}$, and a slip of $20 \mathrm{~m}$ (from standard scaling laws; Schwartz and Coppersmith, 1984) would be $M_{\mathrm{w}}$ 9.3. The analysis presented here is insufficient to identify the cause for this result. This example shows that the method we propose can yield unreliable results in subduction zones with very low seismicity and complex behavior. The turbidite record from the past 10,000 yrs potentially suggests a supercycle with clustering of several great earthquakes close in time to each other, separated by unusually long gaps of few to no earthquakes (Goldfinger et al., 2012). A more sophisticated analysis is warranted to explore the implications for the moment budget of slow-slip events, variations of coupling with space and time (Bruhat and Segall, 2016), and possible anelastic deformation of the fore-arc. This analysis should also look into the in-depth characteristics of the seismicity and their implications for our analysis (e.g., the productivity of aftershocks, a $b$-value that changes during the seismic cycle, etc.).

\section{Boconó Fault}

This fault is a right-lateral strike-slip fault that stretches roughly $500 \mathrm{~km}$ from the Colombian-Venezuelan border in the southwest to the Caribbean coast in the northeast, through the Venezuelan Andes. Rates of 5-9 mm/yr have been suggested for this fault (Schubert and Sifontes, 1970; Audemard et al., 1999; Audemard, 2005), taking up most of the $10 \mathrm{~mm} / \mathrm{yr}$ full plate motion. We take a rate of 

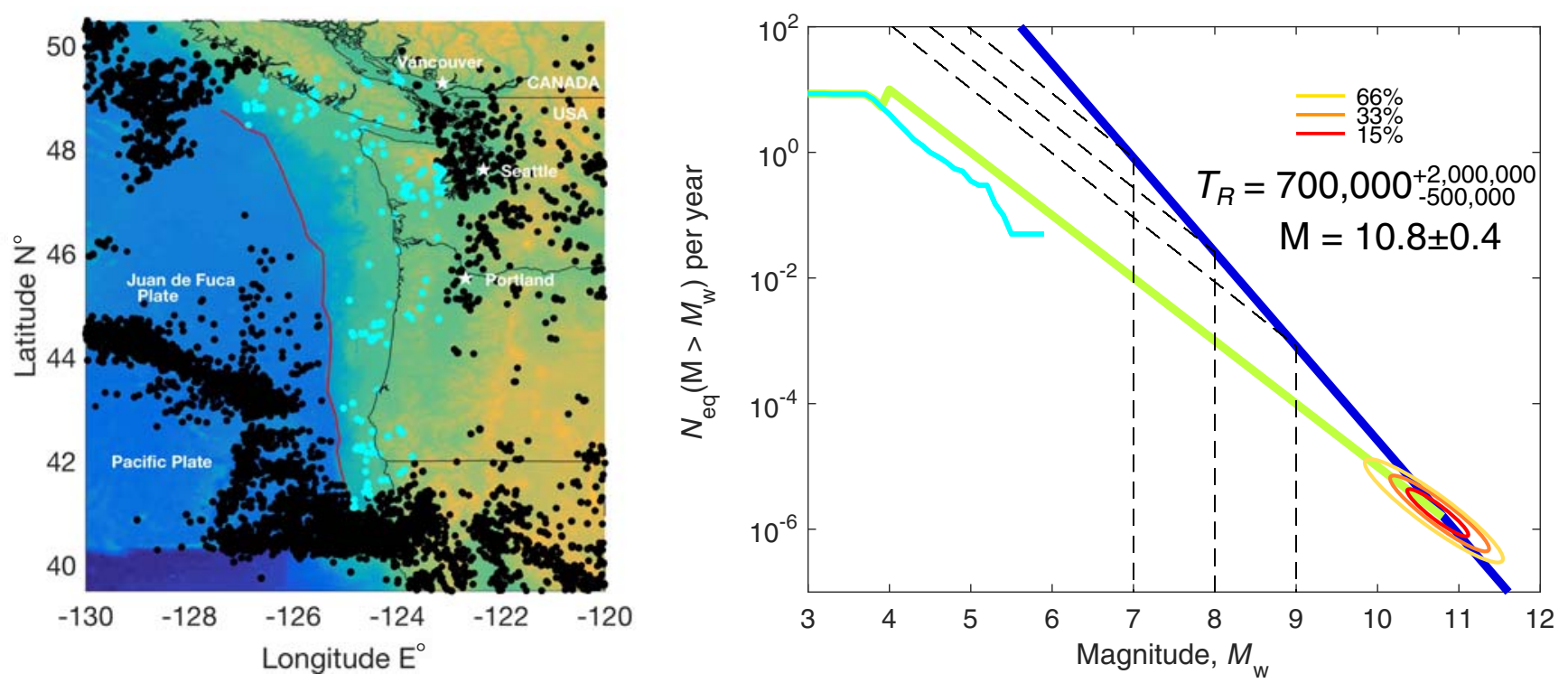

Figure 9. Results of the model for the Cascadia subduction zone. The color version of this figure is available only in the electronic edition.

$7 \pm 2 \mathrm{~mm} / \mathrm{yr}$. Here, we select earthquakes within $20 \mathrm{~km}$ of the fault trace to allow for larger errors in the location of the fault trace and earthquake epicenters. Microseismicity has been found mainly between 0 and $15 \mathrm{~km}$ depth (Pérez et al., 1997), with some microseismicity in the lower crust (Audemard et al., 2008). We take the default coupled width of $12.5 \pm 2.5 \mathrm{~km}$.

We find that the mean $M_{\max }$ is $7.3 \pm 0.3$ (see Fig. 10). The mean recurrence time would be 160 years, with an upper bound of 360 years and a lower bound of 70 years. In more recent times, the largest earthquakes have been one of $M_{\mathrm{w}} 5.5$ in 1975 and one of $M_{\mathrm{w}} 5.6$ in 1977. However, historical earthquakes in 1610 and 1894 may have had magnitudes of 7.1-7.3; evidence of this has been found during trench excavations in the southern section (Audemard, 1997), with a suggested recurrence time of about 300 years in this area. In the central section, at least 15 earthquakes of $M_{\mathrm{w}}>7$ have been found during the past 20,000 years, likely with quite a few missing (Audemard et al., 2008). Recurrence intervals were found to be variable, from 400 years up to 1800 years. An event in 1812 caused a lot of damage, devastating the town of Mérida; it was felt as far away as Caracas, with the Boconó fault a possible source (Altez, 2005; Audemard et al., 2008), though this has not been confirmed. From scaling relations of fault length, $M_{\max }$ has been suggested to be between 7.2 and 7.9 (Schubert, 1982).

\section{Altyn Tagh Fault}

The Altyn Tagh is a large left-lateral strike-slip fault bordering the northwest side of the Tibetan plateau. There have been no large earthquakes recorded instrumentally, though the fault has an offset of about $475 \mathrm{~km}$ since around $25 \mathrm{Ma}$, and there is evidence of large ruptures in the past (Washburn et al., 2003). Slip rates on the Altyn Tagh are roughly $10 \mathrm{~mm} / \mathrm{yr}$
(Elliott et al., 2008; Cowgill et al., 2009), and we use our default coupled depth of $12.5 \pm 2.5 \mathrm{~km}$, consistent with estimates of the locking depth here (Elliott et al., 2008).

We find the mean $M_{\max }$ of $8 \pm 0.3$, with a recurrence time of 900 years, up to 2000 years and down to 400 years (see Fig. 11). There is evidence for two or three events in the central section of the Atyn Tagh during the past 2000 years, with a magnitude of roughly between 7 and 7.8 (Washburn et al., 2003). This is consistent with our model.

\section{Dead Sea Transform}

The Dead Sea Transform (DST) is a 1000-km-long continental left-lateral north-south-trending, strike-slip fault. It has a long, yet incomplete, historical record and some paleoseismic data. The DST has an average slip rate of about $5 \mathrm{~mm} / \mathrm{yr}$ (Garfunkel et al., 1981; Klinger et al., 2000; Wdowinski et al., 2004; Reilinger et al., 2006; Le Beon et al., 2008 ) and a locking depth of about 12-14 km (Salamon et al., 2003; Le Beon et al., 2008).

We find that $M_{\max }$ is $7.8 \pm 0.3$, with a recurrence time of 1000 years, a lower estimate of 450 years, and a higher estimate of 2400 years (see Fig. 12). The largest earthquake recorded was one of a potential magnitude of 7.8 in A.D. 1157 (Ambraseys and Jackson, 1998). More recently, the largest event has been one of a magnitude 7.3 event in 1995 in the Gulf of Aqaba. Other estimates of $M_{\max }$ suggest up to $M_{\mathrm{w}} 7.8$ in the southern section (Klinger et al., 2015) and up to 7.4-7.7 in the Dead Sea basin region (Begin et al., 2005). It has been noted that the seismicity on the DST has been very low this past century with the seismic moment release less than $40 \%$ of that expected (Salamon et al., 2003), and $86 \%$ of that value coming from one earthquake, the $M_{\mathrm{w}} 7.3$ Gulf of Aqaba event. Seismicity has also been low for the past 830 years (Meghraoui, 2014), with periods of 

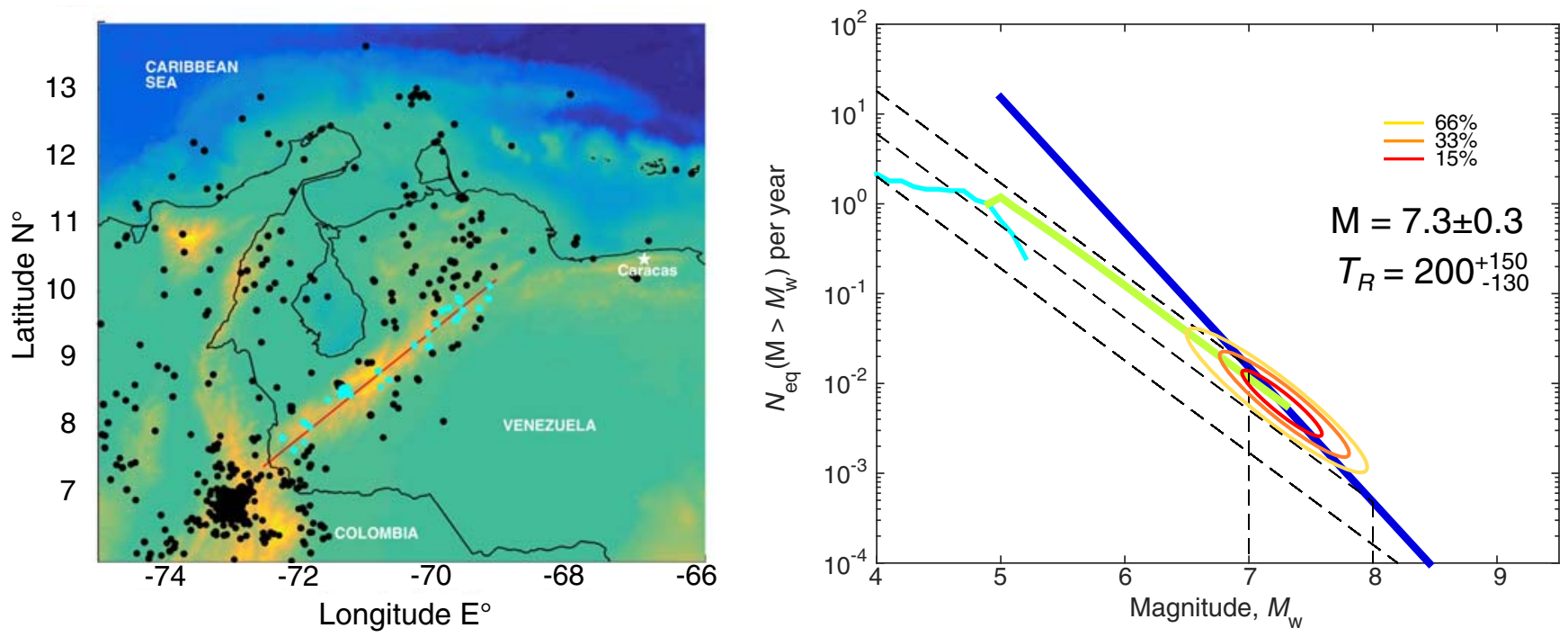

Figure 10. Results of the model for the Boconó Fault. The color version of this figure is available only in the electronic edition.
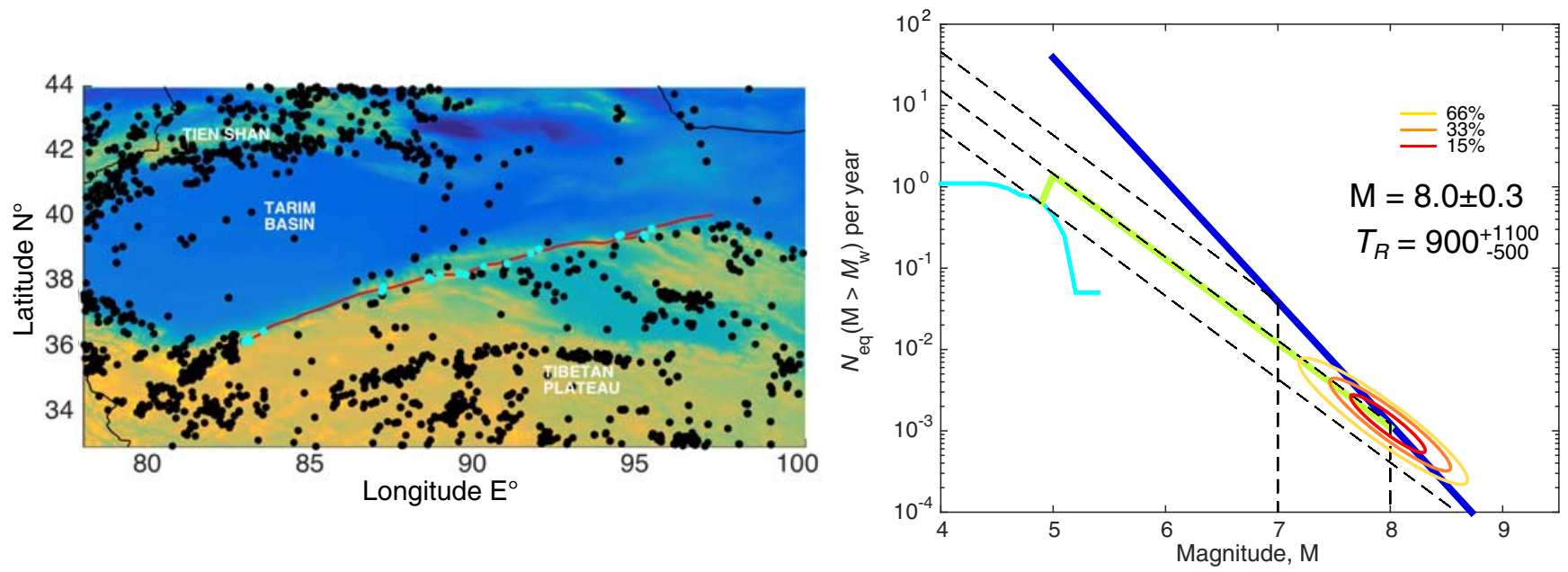

Figure 11. Results of the model for the Altyn Tagh Fault. The color version of this figure is available only in the electronic edition.

quiescence that have been interspersed with higher rates (Marco and Agnon, 1995; Klinger et al., 2015). In the Araba Valley segment (160 km of the almost 1000-km DST length), there have been at least four events of $M_{\mathrm{w}}>7$ in the past 1000 years (Klinger et al., 2000), giving a recurrence time of roughly 250 years. Our model suggests an $M_{\mathrm{w}}>7$ should occur roughly once every 115 years; however, our model is for the entire length of the DST, whereas the Araba Valley segment covers only around one-fifth of the fault. The paleoseismic data do not disagree with our model, though the earthquake rate seems quite variable through time (Daëron et al., 2007).

\section{Kunlun Fault}

The Kunlun fault is a large strike-slip fault in northern Tibet. It slips at a fairly constant rate of $11.7 \pm 1.5 \mathrm{~mm} / \mathrm{yr}$
(Van Der Woerd et al., 2002), and we use the default locking depth of $12.5 \pm 2.5 \mathrm{~km}$.

We find that $M_{\max }$ is $8 \pm 0.3$ with a recurrence time of 1000 years, with a lower bound of 450 years and an upper bound of 2000 years (see Fig. 13). The largest earthquake we know of on the Kunlun fault happened recently, in 2001 $\left(M_{\mathrm{w}} 7.8\right)$, with a 450-km-long rupture. There have not been paleoseismic studies. From minimum terrace offsets and the average slip rate, Van Der Woerd et al. (2002) suggested that earthquakes of around $M_{\mathrm{w}} 8$ could occur on this fault once every $800-1000$ years. The model here is consistent with that idea.

\section{Uncertainties and Discussion}

We have shown that our model predicts the average seismic catalog well in cases where we have historical data. 

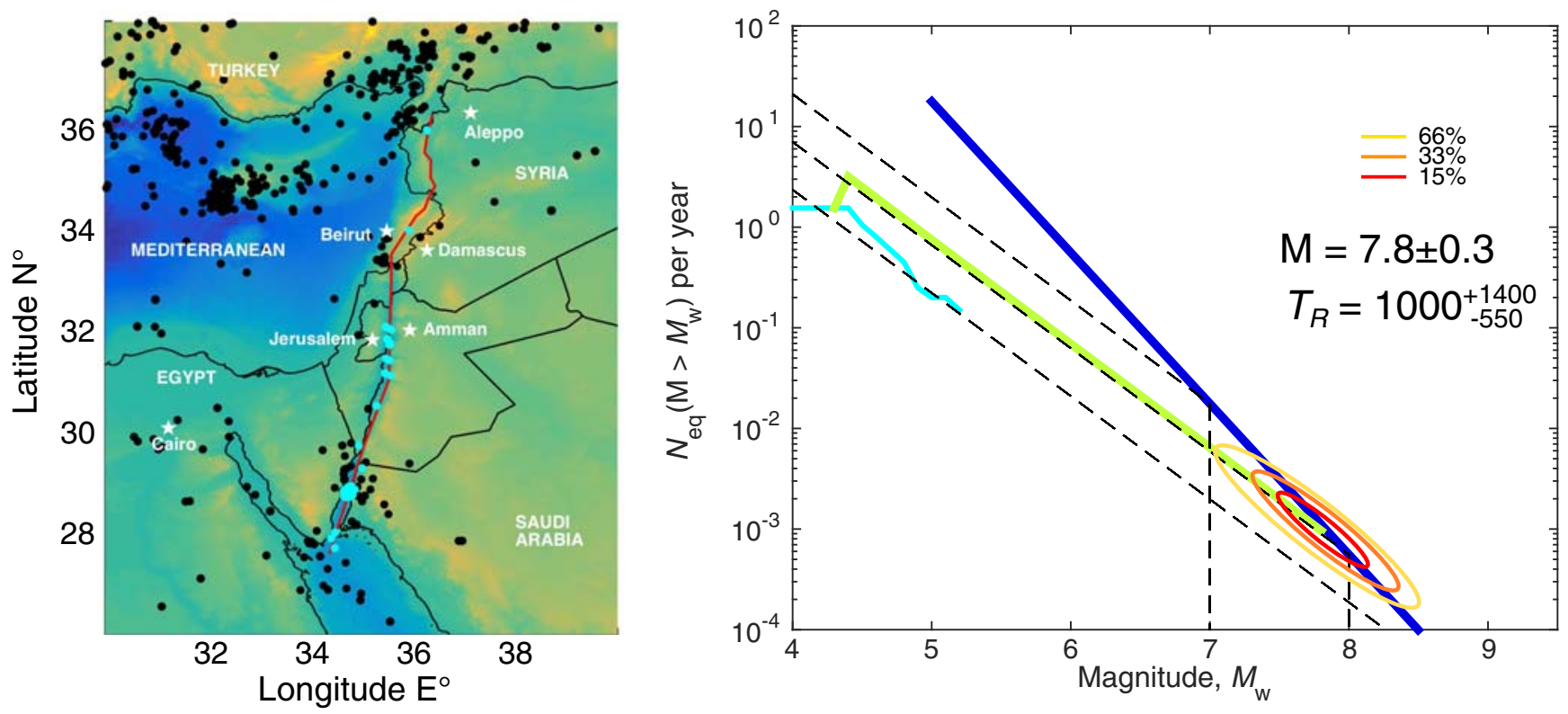

Figure 12. Results of the model for the Dead Sea Transform. The color version of this figure is available only in the electronic edition.
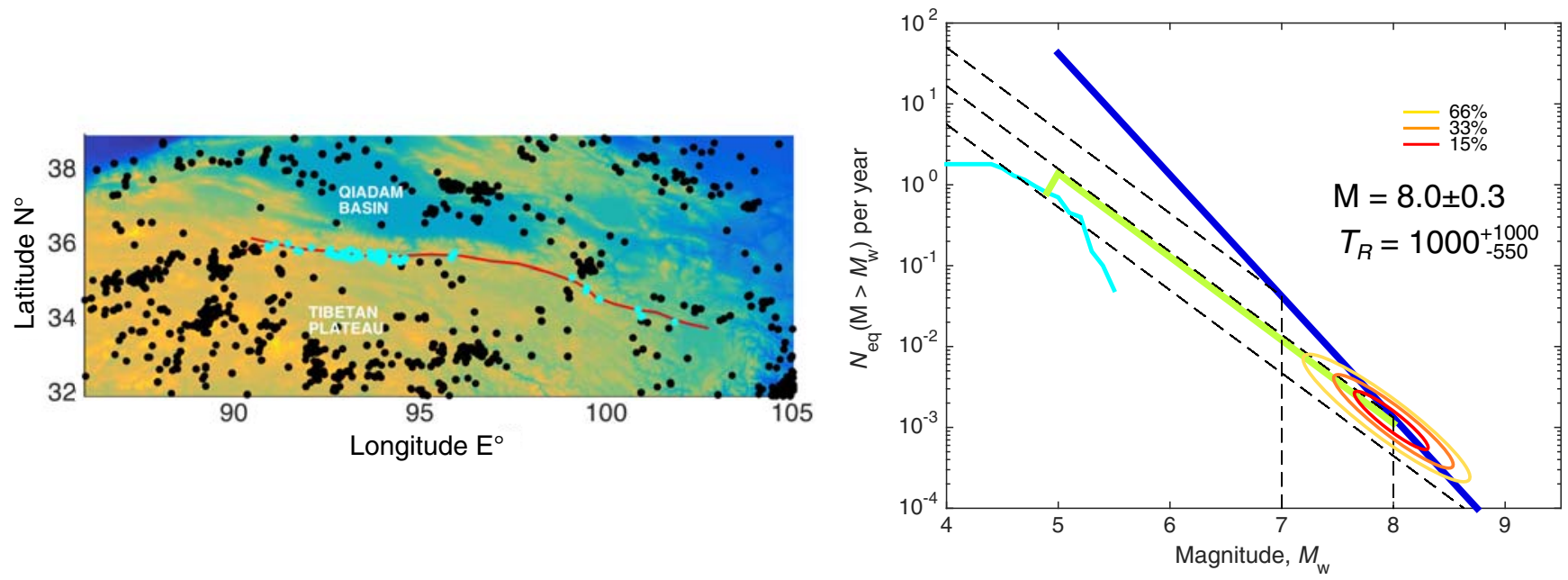

Figure 13. Results of the model for the Kunlun Fault. The color version of this figure is available only in the electronic edition.

In these places, either the historical catalog is complete, or we have not yet seen $M_{\max }$. Errors in the historical catalog are hard to measure and quantify, and they become more pronounced as we look further back in time. Earthquake magnitudes are hard to measure accurately from shaking reports and scaling laws. Even if the magnitudes are well known, the recurrence times may not be, as they are variable and many data points have to be found to get a reliable probability density function (Parsons, 2002). $M_{\max }$ has the longest recurrence time, so this is the most likely to be missed in the historical record.

In this study, we estimated $M_{\max }$ (the absolute maximum magnitude earthquake); however, there are other parameters commonly investigated while studying the earthquakes of largest magnitudes. These include the probable maximum magnitude within a certain time frame $T\left(m_{p}(T)\right)$ and the corner magnitude $\left(m_{\mathrm{c}}\right)$ of a tapered GR distribution. In global studies, Bird and Kagan (2004) found the $m_{\mathrm{c}}$ of continental strike-slip faults to be $8.01_{-0.21}^{+0.47}$ and for subduction zones $9.58_{-0.46}^{+0.48}$. Other estimates for subduction zones include $m_{\mathrm{c}}=9-9.7$ (Kagan and Jackson, 2013) and $m_{p}(T) \geq 9$, in which $T=10,000$ yrs (Rong et al., 2014).

The main advantage of our method is that it can be used in areas with no historical data. It also does not require artificial segmentation, it requires no prior knowledge of parameters, and the process of accounting for uncertainties 


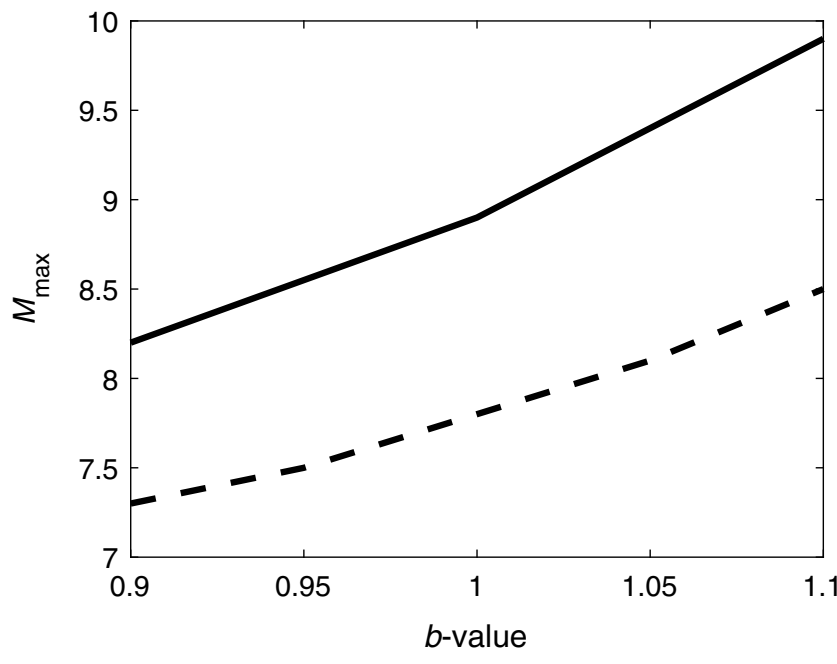

Figure 14. The effect of changing the $b$-value on the predicted maximum magnitude for the Main Himalayan thrust (solid line) and SAFS (dashed line).

is relatively simple. There is a trade-off in the model between errors in the $b$-value and uncertainties in the average frequency of earthquakes. Smaller earthquakes are more likely to be accurate in terms of frequency, but because they are far from $M_{\max }$, projecting using the $b$-value from here causes larger uncertainties. For larger earthquakes, the frequency is less well known, though uncertainty in the $b$-value will introduce fewer errors because it does not have to project so far. If the $b$-value is increased, the estimated $M_{\max }$ also increases, with a change of $b$-value from 0.9 to 1.1. This increases the $M_{\max }$ value by roughly $1-1.5$, as shown in Figure 14.

One disadvantage of this model is that it assumes that the seismicity follows the GR law up to $M_{\max }$, which might not be applicable everywhere. It is possible to change this, though it would involve more parameters. These parameters might not be known well, especially in places with no historical data. Uncertainties in the $b$-value lead to large uncertainties in the results, especially for larger earthquakes. Choosing which earthquakes are on the fault itself, as well as the moment buildup rate on the fault, might be difficult (though other methods also suffer from this problem, and data will surely get better in the future, especially as more Global Positioning System stations are introduced). Another disadvantage of our technique is that it cannot incorporate historical data recurrence times, as they are often not on the same trend as the instrumental data. However, the historical data can be used to validate the model, though perhaps these data are not as accurate as those with smaller magnitudes.

Afterslip is another unknown in the model, and we have just assigned $0 \%-20 \%$ in all cases. For continental earthquakes, this can be small (e.g., $<10 \%$ for the Gorkha earthquake) but is sometimes very significant $(\approx 56 \%$ for the Kashmir earthquake; Jouanne et al., 2011). Afterslip also varies in subduction zones; it can be as low as $20 \%-30 \%$ after the $M_{\mathrm{w}} 8.8$ Chile event (Lin et al., 2013) or as high as 50\%-70\% for the Peruvian trench (Perfettini et al., 2010).

\section{Conclusion}

The estimates presented here are based on crude assumptions and can be revised with improved constraints on the model parameters (such as interseismic coupling or better local seismicity catalogs). Where others have estimated $M_{\max }$ or there are paleoseismic data, our results generally agree with expected values. For areas without the historical data, fewer people have attempted to find $M_{\max }$. For these faults in particular, our model highlights the seismic risk where no large earthquakes have occurred in the recent past. These areas are particularly vulnerable, as the earthquake hazard perception and preparedness is low.

\section{Data and Resources}

The U.S. Geological Survey (USGS) database was searched using http://earthquake.usgs.gov/earthquakes/ search/ (last accessed September 2016). All other data used in this article came from published sources that are listed in the references.

\section{Acknowledgments}

The authors would like to thank two anonymous reviewers, Art McGarr, and Editor-in-Chief Thomas Pratt, for useful suggestions that improved this article.

\section{References}

Ader, T., J.-P. Avouac, J. Liu-Zeng, H. Lyon-Caen, L. Bollinger, J. Galetzka, J. Genrich, M. Thomas, K. Chanard, S. N. Sapkota, et al. (2012). Convergence rate across the Nepal Himalaya and interseismic coupling on the Main Himalayan thrust: Implications for seismic hazard, J. Geophys. Res. 117, no. B4, doi: 10.1029/2011JB009071.

Akçiz, S. O., L. G. Ludwig, J. R. Arrowsmith, and O. Zielke (2010). Century-long average time intervals between earthquake ruptures of the San Andreas fault in the Carrizo Plain, California, Geology 38, no. 9, 787-790.

Aki, K. (1965). Maximum likelihood estimate of $b$ in the formula $\log n=$ $a-b m$ and its confidence limits, Bull. Earthq. Res. Inst. 43, 237-239.

Altez, R. (2005). Los sismos del 26 de marzo de 1812 en Venezuela: nuevos aportes y evidencias sobre estos eventos, Boletín Técnico 43, 11-34 (in Spanish).

Ambraseys, N. N., and J. Jackson (1998). Faulting associated with historical and recent earthquakes in the eastern Mediterranean region, Geophys. J. Int. 133, no. 2, 390-406.

Audemard, F., D. Pantosti, M. Machette, C. Costa, K. Okumura, H. Cowan, H. Diederix, and C. Ferrer (1999). Trench investigation along the Mérida section of the Boconó fault (central Venezuelan Andes), Venezuela, Tectonophysics 308, nos. 1/2, 1-21.

Audemard, F. A. (1997). Holocene and historical earthquakes on the Boconó fault system, southern Venezuelan Andes: Trench confirmation, $J$. Geodyn. 24, nos. 1/4, 155-167.

Audemard, F. A. (2005). Paleoseismology in Venezuela: Objectives, methods, applications, limitations and perspectives, Tectonophysics 408, nos. 1/4, 29-61.

Audemard, F. A., R. Ollarves, M. Bechtold, G. Dãaz, C. Beck, E. Carrillo, D. Pantosti, and H. Diederix (2008). Trench investigation on the main 
strand of the Boconó fault in its central section, at Mesa del Caballo, Mérida Andes, Venezuela, Tectonophysics 459, nos. 1/4, 38-53.

Avouac, J.-P. (2015). From geodetic imaging of seismic and aseismic fault slip to dynamic modeling of the seismic cycle, Annu. Rev. Earth Planet. Sci. 43, no. 1, 233-271.

Bakun, W. H. (1999). Seismic activity of the San Francisco Bay region, Bull. Seismol. Soc. Am. 89, no. 3, 764-784.

Båth, M. (1965). Lateral inhomogeneities of the upper mantle, Tectonophysics 2 , no. 6, 483-514.

Begin, Z., D. Steinberg, G. Ichinose, and S. Marco (2005). A 40,000 year unchanging seismic regime in the Dead Sea rift, Geology 33, no. 4, 257-260.

Bilham, R., R. Engdahl, N. Feldl, and S. P. Satyabala (2005). Partial and complete rupture of the Indo-Andaman plate boundary 1847-2004, Seismol. Res. Lett. 76, no. 3, 299-311.

Bird, P., and Y. Y. Kagan (2004). Plate-tectonic analysis of shallow seismicity: Apparent boundary width, beta, corner magnitude, coupled lithosphere thickness, and coupling in seven tectonic settings, Bull. Seismol. Soc. Am. 94, no. 6, 2380-2399.

Bird, P., D. D. Jackson, Y. Y. Kagan, C. Kreemer, and R. S. Stein (2015) Gear1: A global earthquake activity rate model constructed from geodetic strain rates and smoothed seismicity, Bull. Seismol. Soc. Am. 105, no. $5,2538-2554$.

Bohnhoff, M., P. Martínez-Garzón, F. Bulut, E. Stierle, and Y. Ben-Zion (2016). Maximum earthquake magnitudes along different sections of the North Anatolian fault zone, Tectonophysics 674, 147-165.

Bruhat, L., and P. Segall (2016). Coupling on the northern Cascadia subduction zone from geodetic measurements and physics-based models, $J$. Geophys. Res. 121, no. 11, 8297-8314, doi: 10.1002/2016JB013267.

Brune, J. N. (1968). Seismic moment, seismicity, and rate of slip along major fault zones, J. Geophys. Res. 73, no. 2, 777-784.

Chlieh, M., J.-P. Avouac, V. Hjorleifsdottir, T.-R. A. Song, C. Ji, K. Sieh, A. Sladen, H. Hebert, L. Prawirodirdjo, Y. Bock, et al. (2007). Coseismic slip and afterslip of the great $M_{\mathrm{w}} 9.15$ Sumatra-Andaman earthquake of 2004, Bull. Seismol. Soc. Am. 97, no. 1A, S152-S173.

Chlieh, M., J. P. Avouac, K. Sieh, D. H. Natawidjaja, and J. Galetzka (2008). Heterogeneous coupling of the Sumatran megathrust constrained by geodetic and paleogeodetic measurements, J. Geophys. Res. 113, no. B5, doi: 10.1029/2007JB004981.

Cowgill, E., R. Gold, C. Xuanhua, W. Xiao-Feng, J. Arrowsmith, and J. Southon (2009). Low quaternary slip rate reconciles geodetic and geologic rates along the Altyn Tagh fault, northwestern Tibet, Geology 37, no. 7, 647-650.

Daëron, M., Y. Klinger, P. Tapponnier, A. Elias, E. Jacques, and A. Sursock (2007). 12,000-year-long record of 10 to 13 paleoearthquakes on the Yammoûneh fault, Levant fault system, Llebanon, Bull. Seismol. Soc. Am. 97, no. 3, 749-771.

Dragert, H., R. D. Hyndman, G. C. Rogers, and K. Wang (1994). Current deformation and the width of the seismogenic zone of the northern Cascadia subduction thrust, J. Geophys. Res. 99, no. B1, 653-668.

Elliott, J. R., J. Biggs, B. Parsons, and T. J. Wright (2008). InSAR slip rate determination on the Altyn Tagh fault, northern Tibet, in the presence of topographically correlated atmospheric delays, Geophys. Res. Lett. 35, L12309, doi: 10.1029/2008GL033659.

Felzer, K. R. (2006). Calculating the Gutenberg-Richter $b$ value, Eos Trans. $A G U$ 87, no. 52 (Fall Meet.), Abstract.

Felzer, K. R. (2008). Calculating California seismicity rates, U.S. Geol. Surv. Open-File Rept. 2007-1437I.

Felzer, K. R., R. E. Abercrombie, and G. Ekström (2004). A common origin for aftershocks, foreshocks, and multiplets, Bull. Seismol. Soc. Am. 94, no. $1,88-98$.

Felzer, K. R., T. W. Becker, R. E. Abercrombie, G. Ekström, and J. R. Rice (2002). Triggering of the $1999 M_{\mathrm{w}} 7.1$ Hector Mine earthquake by aftershocks of the $1992 M_{\mathrm{w}} 7.3$ Landers earthquake, J. Geophys. Res. 107, no. B9, 6-13.

Field, E. H., R. J. Arrowsmith, G. P. Biasi, P. Bird, T. E. Dawson, K. R. Felzer, D. D. Jackson, K. M. Johnson, T. H. Jordan, C. Madden, et al.
(2014). Uniform California Earthquake Rupture Forecast, Version 3 (UCERF3)-The time-independent model, Bull. Seismol. Soc. Am. 104, no. 3, 1122-1180.

Field, E. H., D. D. Jackson, and J. F. Dolan (1999). A mutually consistent seismic-hazard source model for southern California, Bull. Seismol. Soc. Am. 89, no. 3, 559-578.

Fry, B., and K.-F. Ma (2016). Implications of the great $M_{\mathrm{w}} \sim 9.0$ TohokuOki earthquake on the understanding of natural hazard in Taiwan and New Zealand, Seismol. Res. Lett. 87, no. 6, 1254-1258.

Garfunkel, Z., I. Zak, and R. Freund (1981). The Dead Sea rift active faulting in the Dead Sea rift, Tectonophysics 80, no. 1, 1-26.

Goldfinger, C., C. H. Nelson, A. E. Morey, J. E. Johnson, J. R. Patton, E. Karabanov, J. Gutierrez-Pastor, A. T. Eriksson, E. Gracia, G. Dunhill, et al. (2012). Turbidite event history: Methods and implications for Holocene paleoseismicity of the Cascadia subduction zone, U.S. Geol. Surv. Profess. Pap. 1661-F, $170 \mathrm{pp}$.

Grunewald, E. D., and R. S. Stein (2006). A new 1649-1884 catalog of destructive earthquakes near Tokyo and implications for the long-term seismic process, J. Geophys. Res. 111, no. B12, doi: 10.1029/ 2005JB004059.

Gutenberg, B., and C. F. Richter (1944). Frequency of earthquakes in California, Bull. Seismol. Soc. Am. 34, no. 4, 185-188.

Hartleb, R. D., J. F. Dolan, Ö. Kozaci, H. S. Akyüz, and G. G. Seitz (2006). A 2500-yr-long paleoseismologic record of large, infrequent earthquakes on the North Anatolian fault at Çukurçimen, Turkey, Geol. Soc. Am. Bull. 118, nos. 7/8, 823-840.

Hashimoto, C., A. Noda, T. Sagiya, and M. Matsu'ura (2009). Interplate seismogenic zones along the Kuril-Japan trench inferred from GPS data inversion, Nature Geosci. 2, no. 2, 141-144.

Helmstetter, A., and D. Sornette (2003). Båth's law derived from the Gutenberg-Richter law and from aftershock properties, Geophys. Res. Lett. 30, 2069.

Helmstetter, A., Y. Y. Kagan, and D. D. Jackson (2005). Importance of small earthquakes for stress transfers and earthquake triggering, J. Geophys. Res. 110, no. B5, doi: 10.1029/2004JB003286.

Holschneider, M., G. Zöller, and S. Hainzl (2011). Estimation of the maximum possible magnitude in the framework of a doubly truncated Gutenberg-Richter model, Bull. Seismol. Soc. Am. 101, no. 4, 16491659.

Hussain, E., A. Hooper, T. J. Wright, R. J. Walters, and D. P. S. Bekaert (2016). Interseismic strain accumulation across the central North Anatolian fault from iteratively unwrapped InSAR measurements, $J$. Geophys. Res. 121, 9000-9019, doi: 10.1002/2016JB013108.

Hutton, K., J. Woessner, and E. Hauksson (2010). Earthquake monitoring in southern California for seventy-seven years (1932-2008), Bull. Seismol. Soc. Am. 100, no. 2, 423-446.

Hyndman, R. D. (2013). Downdip landward limit of cascadia great earthquake rupture, J. Geophys. Res. 118, no. 10, 5530-5549.

Ishimura, D., and T. Miyauchi (2015). Historical and paleo-tsunami deposits during the last 4000 years and their correlations with historical tsunami events in Koyadori on the Sanriku Coast, northeastern Japan, Progr. Earth Planet. Sci. 2, no. 1, 1-18.

Jouanne, F., A. Awan, A. Madji, A. Pêcher, M. Latif, A. Kausar, J. L. Mugnier, I. Khan, and N. A. Khan (2011). Postseismic deformation in Pakistan after the 8 October 2005 earthquake: Evidence of afterslip along a flat north of the Balakot-Bagh thrust, J. Geophys. Res. 116, no. B7, doi: 10.1029/2010JB007903.

Kagan, Y. Y., and D. D. Jackson (2012). Whole earth high-resolution earthquake forecasts, Geophys. J. Int. 190, no. 1, 677-686.

Kagan, Y. Y., and D. D. Jackson (2013). Tohoku earthquake: A surprise? Bull. Seismol. Soc. Am. 103, no. 2B, 1181-1194.

Kao, H., K. Wang, H. Dragert, J. Y. Kao, and G. Rogers (2010). Estimating seismic moment magnitude $\left(M_{\mathrm{w}}\right)$ of tremor bursts in northern Cascadia: Implications for the "seismic efficiency" of episodic tremor and slip, Geophys. Res. Lett. 37, L19306, doi: 10.1029/2010GL044927.

Kijko, A. (2004). Estimation of the maximum earthquake magnitude, $M_{\max }$, Pure Appl. Geophys. 161, no. 8, 1655-1681. 
Kijko, A., and G. Graham (1998). Parametric-historic procedure for probabilistic seismic hazard analysis. Part I: Estimation of maximum regional magnitude $M_{\max }$, Pure Appl. Geophys. 152, no. 3, 413-442.

Klinger, Y., J. P. Avouac, N. Abou Karaki, L. Dorbath, D. Bourles, and J. L. Reyss (2000). Slip rate on the Dead Sea transform fault in northern Araba Valley (Jordan), Geophys. J. Int. 142, no. 3, 755-768.

Klinger, Y., M. Le Béon, and M. Al-Qaryouti (2015). 5000 yr of paleoseismicity along the southern Dead Sea fault, Geophys. J. Int. 202, no. 1, 313-327.

Klinger, Y., K. Sieh, E. Altunel, A. Akoglu, A. Barka, T. Dawson, T. Gonzalez, A. Meltzner, and T. Rockwell (2003). Paleoseismic evidence of characteristic slip on the western segment of the North Anatolian fault, Turkey, Bull. Seismol. Soc. Am. 93, no. 6, 2317-2332.

Kohlstedt, D. L., B. Evans, and S. J. Mackwell (1995). Strength of the lithosphere: Constraints imposed by laboratory experiments, J. Geophys. Res. 100, no. B9, 17,587-17,602.

Kozaci, Ö., J. Dolan, R. Finkel, and R. Hartleb (2007). Late Holocene slip rate for the North Anatolian fault, Turkey, from cosmogenic $36 \mathrm{Cl}$ geochronology: Implications for the constancy of fault loading and strain release rates, Geology 35, no. 10, 867-870.

Kumar, S., S. G. Wesnousky, R. Jayangondaperumal, T. Nakata, Y. Kumahara, and V. Singh (2010). Paleoseismological evidence of surface faulting along the northeastern Himalayan front, India: Timing, size, and spatial extent of great earthquakes, J. Geophys. Res. 115, no. B12422, doi: 10.1029/2009JB006789.

Lavé, J., D. Yule, S. Sapkota, K. Basant, C. Madden, M. Attal, and R. Pandey (2005). Evidence for a great medieval earthquake ( 1100 A.D.) in the central Himalayas, Nepal, Science 307, no. 5713, 1302-1305.

Lay, T., H. Kanamori, C. J. Ammon, M. Nettles, S. N. Ward, R. C. Aster, S. L. Beck, S. L. Bilek, M. R. Brudzinski, R. Butler, et al. (2005). The great Sumatra-Andaman earthquake of 26 December 2004, Science 308, no. 5725, 1127-1133.

Le Beon, M., Y. Klinger, A. Q. Amrat, A. Agnon, L. Dorbath, G. Baer, J.-C. Ruegg, O. Charade, and O. Mayyas (2008). Slip rate and locking depth from GPS profiles across the southern Dead Sea transform, J. Geophys. Res. 113, no. B11403, doi: 10.1029/2007JB005280.

Lin, Y.-n. N., A. Sladen, F. Ortega-Culaciati, M. Simons, J.-P. Avouac, E. J. Fielding, B. A. Brooks, M. Bevis, J. Genrich, A. Rietbrock, et al. (2013). Coseismic and postseismic slip associated with the 2010 Maule earthquake, Chile: Characterizing the Arauco Peninsula barrier effect, J. Geophys. Res. 118, no. 6, 3142-3159.

Loveless, J. P., and B. J. Meade (2010). Geodetic imaging of plate motions, slip rates, and partitioning of deformation in Japan, J. Geophys. Res. 115, no. B02410, doi: 10.1029/2008JB006248.

Loveless, J. P., and B. J. Meade (2015). Kinematic barrier constraints of the magnitudes of additional great earthquakes off the east coast of Japan, Seismol. Res. Lett. 86, no. 1, doi: 10.1785/0220140083.

Marco, S., and A. Agnon (1995). Prehistoric earthquake deformations near Masada, Dead Sea graben, Geology 23, no. 8, 695-698.

Marsan, D., and O. Lengliné (2008). Extending earthquakes' reach through cascading, Science 319, no. 5866, 1076-1079.

McCaffrey, R. (2008). Global frequency of magnitude 9 earthquakes, Geology 36, no. 3, 263-266.

Meade, B. J., and B. H. Hager (2005). Block models of crustal motion in southern California constrained by GPS measurements, J. Geophys. Res. 110, no. B03403, doi: 10.1029/2004JB003209.

Meghraoui, M. (2014). Paleoseismic history of the Dead Sea fault zone, in Encyclopedia of Earthquake Engineering, M. Beer, I. A. Kougioumtzoglou, E. Patelli, and I. S.-K. Au (Editors), Springer, Berlin/ Heidelberg, Germany, 1-20.

Minoura, K., F. Imamura, D. Sugawara, Y. Kono, and T. Iwashita (2001). The 869 Jogan tsunami deposit and recurrence interval of large-scale tsunami on the Pacific coast of northeast Japan, J. Nat. Disast. Sci. 23, no. $2,82-88$.

Molnar, P. (1979). Earthquake recurrence intervals and plate tectonics, Bull. Seismol. Soc. Am. 69, no. 1, 115-133.
Nanayama, F., K. Satake, R. Furukawa, K. Shimokawa, B. F. Atwater, K. Shigeno, and S. Yamaki (2003). Unusually large earthquakes inferred from tsunami deposits along the Kuril trench, Nature 424, no. 6949, 660-663.

National Geophysical Data Center (NGDC) (2016). Significant Earthquake Database, National Geophysical Data Center

Ogata, Y. (1988). Statistical models for earthquake occurrences and residual analysis for point processes, J. Am. Stat. Assoc. 83, no. 401, 9-27.

Omi, T., Y. Ogata, Y. Hirata, and K. Aihara (2013). Forecasting large aftershocks within one day after the main shock, Sci. Rep. 3, Article Number 2218.

Oppenheimer, D., J. Eaton, A. Jayko, M. Lisowski, G. Marshall, M. Murray, R. Simpson, R. Stein, G. Beroza, M. Magee, et al. (1993). The Cape Mendocino, California, earthquakes of April 1992: Subduction at the triple junction, Science 261, no. 5120, 433-438.

Ozawa, S., T. Nishimura, H. Suito, T. Kobayashi, M. Tobita, and T. Imakiire (2011). Coseismic and postseismic slip of the 2011 magnitude 9 Tohoku-Oki earthquake, Nature 475, no. 7356, 373-376.

Page, M., and K. Felzer (2015). Southern San Andreas fault seismicity is consistent with the Gutenberg-Richter magnitude-frequency distribution, Bull. Seismol. Soc. Am. 105, no. 4, 2070-2080.

Parsons, T. (2002). Global Omori law decay of triggered earthquakes: Large aftershocks outside the classical aftershock zone, J. Geophys. Res. 107, no. B9, ESE 9-1-ESE 9-20.

Parsons, T., R. Console, G. Falcone, M. Murru, and K. Yamashina (2012). Comparison of characteristic and Gutenberg-Richter models for timedependent M 7.9 earthquake probability in the Nankai-Tokai subduction zone, Japan, Geophys. J. Int. 190, no. 3, 1673-1688.

Pérez, O. J., C. Sanz, and G. Lagos (1997). Microseismicity, tectonics and seismic potential in southern Caribbean and northern Venezuela, $J$. Seismol. 1, no. 1, 15-28.

Perfettini, H., J.-P. Avouac, H. Tavera, A. Kositsky, J.-M. Nocquet, F. Bondoux, M. Chlieh, A. Sladen, L. Audin, D. L. Farber, et al. (2010). Seismic and aseismic slip on the central Peru megathrust, Nature 465, no. 7294, 78-81.

Pisarenko, V. F., A. Sornette, D. Sornette, and M. V. Rodkin (2008). New approach to the characterization of $M_{\max }$ and of the tail of the distribution of earthquake magnitudes, Pure Appl. Geophys. 165, no. 5, 847-888.

Pisarenko, V. F., D. Sornette, and M. V. Rodkin (2010). Distribution of maximum earthquake magnitudes in future time intervals: Application to the seismicity of Japan (1923-2007), Earth Planets Space 62, no. 7, 567-578.

Reasenberg, P. A., and L. M. Jones (1989). Earthquake hazard after a mainshock in California, Science 243, no. 4895, 1173-1176.

Reilinger, R., S. McClusky, P. Vernant, S. Lawrence, S. Ergintav, R. Cakmak, H. Ozener, F. Kadirov, I. Guliev, R. Stepanyan, et al. (2006). GPS constraints on continental deformation in the AfricaArabia-Eurasia continental collision zone and implications for the dynamics of plate interactions, J. Geophys. Res. 111, no. B05411, doi: 10.1029/2005JB004051.

Rong, Y., D. D. Jackson, H. Magistrale, and C. Goldfinger (2014). Magnitude limits of subduction zone earthquakes, Bull. Seismol. Soc. Am. 104, no. 5, 2359-2377.

Salamon, A., A. Hofstetter, Z. Garfunkel, and H. Ron (2003). Seismotectonics of the Sinai subplate-The eastern Mediterranean region, Geophys. J. Int. 155, no. 1, 149-173.

Satake, K. (2015). Geological and historical evidence of irregular recurrent earthquakes in Japan, Phil. Trans. Roy. Soc. Lond. A 373, no. 2053, doi: 10.1098/rsta.2014.0375.

Satake, K., K. Wang, and B. F. Atwater (2003). Fault slip and seismic moment of the 1700 Cascadia earthquake inferred from Japanese tsunami descriptions, J. Geophys. Res. 108, no. B11, 2535.

Savage, J. C., M. Lisowski, and W. H. Prescott (1991). Strain accumulation in western Washington, J. Geophys. Res. 96, no. B9, 14,493-14,507.

Scharer, K. M., G. P. Biasi, R. J. Weldon, and T. E. Fumal (2010). Quasi-periodic recurrence of large earthquakes on the southern San Andreas fault, Geology 38, no. 6, 555-558. 
Schubert, C. (1982). Neotectonics of Boconó fault, western Venezuela, Tectonophysics 85, no. 3, 205-220.

Schubert, C., and R. S. Sifontes (1970). Boconó fault, Venezuelan Andes: Evidence of postglacial movement, Science 170, no. 3953, 66-69.

Schwartz, D., and K. Coppersmith (1984). Fault behavior and characteristic earthquakes: Examples from the Wasatch and San Andreas fault zones, J. Geophys. Res. 89, 5681-5698.

Schwartz, S. Y., and J. M. Rokosky (2007). Slow slip events and seismic tremor at circum-pacific subduction zones, Rev. Geophys. 45, no. 3, RG3004.

Şengör, A., O. Tüysüz, C. Imren, M. Saknç, H. Eyidoğan, N. Görür, X. L. Pichon, and C. Ranginreem (2005). The North Anatolian fault: A new look, Annu. Rev. Earth Planet. Sci. 33, no. 1, 37-112.

Shcherbakov, R., and D. L. Turcotte (2004). A modified form of Båth's law, Bull. Seismol. Soc. Am. 94, no. 5, 1968-1975.

Shearer, P. M. (2012). Self-similar earthquake triggering, Båth's law, and foreshock/aftershock magnitudes: Simulations, theory, and results for southern California, J. Geophys. Res. 117, no. B06310, doi: 10.1029/2011JB008957.

Shinohara, M., Y. Machida, T. Yamada, K. Nakahigashi, T. Shinbo, K. Mochizuki, Y. Murai, R. Hino, Y. Ito, T. Sato, et al. (2013). Precise aftershock distribution of the 2011 off the Pacific coast of Tohoku earthquake revealed by an ocean-bottom seismometer network, Earth Planets Space 64, no. 12, 1137-1148.

Sieh, K., and D. Natawidjaja (2000). Neotectonics of the Sumatran fault, Indonesia, J. Geophys. Res. 105, no. B12, 28,295-28,326.

Sieh, K., L. Jones, E. Hauksson, K. Hudnut, D. Eberhart-Phillips, T. Heaton, S. Hough, K. Hutton, H. Kanamori, A. Lilje, et al. (1993). Near-field investigations of the Landers earthquake sequence, April to July 1992, Science 260, no. 5105, 171-176.

Smith-Konter, B. R., D. T. Sandwell, and P. Shearer (2011). Locking depths estimated from geodesy and seismology along the San Andreas fault system: Implications for seismic moment release, J. Geophys. Res. 116, no. B06401, doi: 10.1029/2010JB008117.

Sokolov, V. Y., C.-H. Loh, and K.-L. Wen (2001). Empirical models for site-and region-dependent ground-motion parameters in the Taipei area: A unified approach, Earthq. Spectra 17, no. 2, 313-331.

Stevens, V. L., and J. P. Avouac (2015). Interseismic coupling on the Main Himalayan thrust, Geophys. Res. Lett. 42, no. 14, 5828-5837.

Stevens, V. L., and J.-P. Avouac (2016). Millenary $M_{\mathrm{w}}>9.0$ earthquakes required by geodetic strain in the Himalaya, Geophys. Res. Lett. 43, no. 3, 1118-1123.

Stover, C. W., and J. L. Coffman (1993). Seismicity of the United States, 1568-1989 (revised). U.S. Geol. Surv. Profess. Pap. 1527, 418 pp.

Tahir, M., and J. R. Grasso (2014). Aftershock patterns of $M_{\mathrm{s}} \geq 7$ earthquakes in the India-Asia collision belt: Anomalous results from the Muzaffarabad earthquake sequence, Kashmir, 2005, Bull. Seismol. Soc. Am. 104, no. 1, 1-23.

Toda, S., and R. S. Stein (2013). The $2011 \mathrm{M}=9.0$ Tohoku Oki earthquake more than doubled the probability of large shocks beneath Tokyo, Geophys. Res. Lett. 40, no. 11, 2562-2566.

Tormann, T., S. Wiemer, and E. Hauksson (2010). Changes of reporting rates in the southern California earthquake catalog, introduced by a new definition of $M_{\mathrm{L}}$, Bull. Seismol. Soc. Am. 100, no. 4, 1733-1742.

Uchida, N., and T. Matsuzawa (2011). Coupling coefficient, hierarchical structure, and earthquake cycle for the source area of the 2011 off the Pacific coast of Tohoku earthquake inferred from small repeating earthquake data, Earth Planets Space 63, no. 7, 675-679.

Upreti, B., T. Nakata, Y. Kumahara, H. Yagi, K. Okumura, T. Rockwell, N. Virdi, and H. Maemoku (2000). The latest active faulting in southeast Nepal, Proc. of the Hokudan International Symposium and School on Active Faulting, 17-26.

Usami, T. (2002). Historical earthquakes in Japan, in International Handbook of Earthquake and Engineering Seismology, H. K. L. William, P. C. J. Hiroo Kanamori, and C. Kisslinger (Editors), Vol. 81, in International Geophysics: Part A, Academic Press, Boston, Massachusetts, 799-802.
Utsu, T. (1965). A method for determining the value of $b$ in the formula $\log n=a-b m$ showing the magnitude-frequency relation for earthquakes, Geophys. Bull. Hokkaido Univ. 13, no. 13, 99-103.

Van Der Woerd, J., P. Tapponnier, F. J. Ryerson, A.-S. Meriaux, B. Meyer, Y. Gaudemer, R. C. Finkel, M. W. Caffee, Z. Guoguang, and X. Zhiqin (2002). Uniform postglacial slip-rate along the central $600 \mathrm{~km}$ of the Kunlun fault (Tibet), from $26 \mathrm{Al}, 10 \mathrm{Be}$, and $14 \mathrm{C}$ dating of riser offsets, and climatic origin of the regional morphology, Geophys. J. Int. 148, no. 3, 356-388.

Wang, Q., D. D. Jackson, and Y. Y. Kagan (2009). California earthquakes, 1800-2007: A unified catalog with moment magnitudes, uncertainties, and focal mechanisms, Seismol. Res. Lett. 80, no. 3, 446-457.

Washburn, Z., J. R. Arrowsmith, G. Dupont-Nivet, W. X. Feng, Z. Y. Qiao, and C. Zhengle (2003). Paleoseismology of the Xorxol segment of the central Altyn Tagh fault, Xinjiang, China, Ann. Geophys. 46, no. 5, doi: 10.4401/ag-3443.

Wdowinski, S., Y. Bock, G. Baer, L. Prawirodirdjo, N. Bechor, S. Naaman, R. Knafo, Y. Forrai, and Y. Melzer (2004). GPS measurements of current crustal movements along the Dead Sea fault, J. Geophys. Res. 109, no. B05403, doi: 10.1029/2003JB002640.

Wech, A. G., and N. M. Bartlow (2014). Slip rate and tremor genesis in Cascadia, Geophys. Res. Lett. 41, no. 2, 392-398.

Wech, A. G., and K. C. Creager (2011). A continuum of stress, strength and slip in the Cascadia subduction zone, Nature Geosci. 4, no. 9, 624-628.

Wells, D. L., and K. J. Coppersmith (1994). New empirical relationships among magnitude, rupture length, rupture width, rupture area, and surface displacement, Bull. Seismol. Soc. Am. 84, no. 4, 974-1002, A1-A4, B1-B11, C1-C49.

Wiemer, S. (2001). A software package to analyze seismicity: ZMAP, Seismol. Res. Lett. 72, no. 3, 373-382.

Wiemer, S., and M. Wyss (2002). Mapping spatial variability of the frequencymagnitude distribution of earthquakes, Adv. Geophys. 45, 259-302.

Williams, M. C., A. M. Tréhu, and J. Braunmiller (2011). Seismicity at the Cascadia plate boundary beneath the Oregon continental shelf, Bull. Seismol. Soc. Am. 101, no. 3, 940-950.

Wilson, D. S. (1993). Confidence intervals for motion and deformation of the Juan de Fuca plate, J. Geophys. Res. 98, no. B9, 16,053-16,071.

Zhan, Z., D. Helmberger, M. Simons, H. Kanamori, W. Wu, N. Cubas, Z. Duputel, R. Chu, V. C. Tsai, and J.-P. Avouac, I (2012). Anomalously steep dips of earthquakes in the 2011 Tohoku-Oki source region and possible explanations, Earth Planet. Sci. Lett. 353/354, 121-133.

Zöller, G., and M. Holschneider (2016). The earthquake history in a fault zone tells us almost nothing about $M_{\max }$, Seismol. Res. Lett. 87, no. 1, 132-137.

Zöller, G., S. Hainzl, and M. Holschneider (2010). Recurrence of large earthquakes: Bayesian inference from catalogs in the presence of magnitude uncertainties, Pure Appl. Geophys. 167, no. 6, 845-853.

Zöller, G., M. Holschneider, S. Hainzl, and J. Zhuang (2014). The largest expected earthquake magnitudes in Japan: The statistical perspective, Bull. Seismol. Soc. Am. 104, no. 2, 769-779.

\section{Appendix}

The maximum earthquake needed, and its return period, is that which balances the seismic moment buildup rate $\dot{M}_{\circ b}$ with the average seismic moment release rate $\dot{M}_{\text {or }}$ of all earthquakes up to and including the maximum earthquake size $M_{\max }$. The moment buildup rate can be found as follows:

$$
\dot{M}_{\circ b}=\mu L W \bar{u},
$$

in which $L$ is the length of the fault, $W$ is the coupled width of the fault (coupled depth multiplied by $\sin (d), d$ is the dip of the fault), $\mu$ is the rigidity, and $\bar{u}$ is the average slip rate. 
To find the average seismic moment release rate of earthquakes, we assume the Gutenberg-Richter (GR) law and a standard conversion law between magnitude and seismic moment. The GR law (Gutenberg and Richter, 1944) states the following:

$$
\log _{10} N\left(M>M_{\mathrm{w}}\right)=a-b M_{\mathrm{w}},
$$

in which $N\left(M>M_{\mathrm{w}}\right)$ is the number of earthquakes above $M_{\mathrm{w}}, a$ is the $y$-axis intercept and can be thought of as the productivity, and $b$ is the slope of the line. Rearranging this equation, we get the following:

$$
N\left(M>M_{\mathrm{w}}\right)=10^{\left(a-b M_{\mathrm{w}}\right)}
$$

and so

$$
N\left(0<M<M_{\mathrm{w}}\right)=10^{a}-10^{\left(a-b M_{\mathrm{w}}\right)},
$$

now $N\left(0<M<M_{\mathrm{w}}\right)$ is the number of earthquakes below $M_{\mathrm{w}}$ and above a magnitude of zero. The conversion between magnitude $M_{\mathrm{w}}$ and seismic moment $M_{\circ}$ in $\mathrm{N} \cdot \mathrm{m}$ used is

$$
M_{\circ}=10^{\alpha M_{\mathrm{w}}+\beta},
$$

in which $\alpha=3 / 2$ and $\beta=9$.

The total moment release can be found by integrating the number of earthquakes and associated moment release up to the maximum-sized earthquake $M_{\max }$ :

$$
M_{\circ r}=\int_{-\infty}^{M_{\max }} M_{\circ}\left(M_{\mathrm{w}}^{\prime}\right) N\left(M_{\mathrm{w}}^{\prime}\right) d M_{\mathrm{w}}^{\prime}
$$

We then get

$$
a=\log _{10} \frac{M_{\circ r}}{10^{\alpha-b M}-1}-\beta-\log _{10} b-\log _{10} 3-b M . \text { (A7) }
$$

The average seismic moment release rate is found by averaging over the return period associated with the maximum-sized earthquake.

$$
N=\log _{10} \frac{\dot{M}_{\circ r}}{10^{\alpha-b M}-1}-\beta-\log _{10} b-\log _{10} 3-b M,
$$

in which $N$ is the frequency of earthquakes. The value of $M_{\text {max }}$ can be found by equating $\dot{M}_{\circ b}$ and $\dot{M}_{\circ r}$.

California Institute of Technology

1200 East California Boulevard

Pasadena, California 91125

vstevens@caltech.edu

Manuscript received 20 January 2017;

Published Online 26 September 2017 